\title{
6 Literaturverzeichnis
}

Das Literaturverzeichnis führt alle direkt und indirekt verwendeten Titel auf. Nicht aufgeführt werden Nachschlagewerke sowie die zur Vorbereitung gesichteten, aber nicht verwendeten Titel.

\subsection{Abkürzungen}

\begin{tabular}{ll}
\hline Sigle & Auflösung \\
\hline DKJ & Morohashi, Tetsuji 諸橋轍次: Dai kanwa jiten 大漢和辞典. 12 Bde. + Index. Tōkyō: \\
& Taishūkan shoten 大修館書店, 1960. \\
\hline KBHT & Kindai bungaku hyōron taikei 近代文学評論大系. 10 Bde. Tōkyō: Kadokawa shoten \\
& 角川書店, 1971-1975.
\end{tabular}

KSDB Kotenseki sōgō dētā bēsu 古典籍総合データーベース unter http://www.wul.waseda. ac.jp/kotenseki/search.php (Zuletzt aufgerufen: 30.11.2021).

KTSM Kotenseki sōgō mokuroku 古典籍総合目録 (Union Catalogue of Early Japanese Books). http://base1.nijl.ac.jp/infolib/meta_pub/G0001401KTG (Zuletzt aufgerufen: 30.11.2021).

MBgZ Meiji bungaku zenshū 明治文学全集. 99 Bde. + Suppl. Tōkyō: Chikuma shobō 筑摩書 房, 1966-1989.

MBkZ Meiji bunka zenshū 明治文化全集. Tōkyō: Nihon hyōron sha 日本評論社, 1967-1974.

NDL National Diet Library (Kokuritsu Kokkai Toshokan 国立国会図書館), http://www.ndl. go.jp/ (Zuletzt aufgerufen: 30.11.2021).

NKBT Nihon koten bungaku taikei 日本古典文学大系. 100 Bde. + Supp. und Indices. Tōkyō: Iwanami shoten 岩波書店, 1958-1968.

NKiBT Nihon kindai bungaku taikei 日本近代文学大系. 61 Bde. Tōkyō: Kadokawa shoten 角川書店, 1970-1975.

NKiST Nihon kindai shisō taikei 日本近代思想大系. 36 Bde. Tōkyō: Iwanami shoten 岩波書 店, 1975-1990.

NOAG Nachrichten der Gesellschaft für Natur- und Völkerkunde Ostasiens. Hamburg: OAG, 1926 -* $^{*}$

NSS Nihon shiwa sōsho 日本詩話叢書. 10 Bde. 2. Aufl. Tōkyō: Ōtori shuppan 鳳出版, 1972 (1. Aufl. Tōkyō: Bunkai dō 文会堂, 1920-1922)

NST Nihon shisō taikei 日本思想大系. 67 Bde. Tōkyō: Iwanami shoten 岩波書店, 1970-1982. 
SKQS Siku quanshu 四庫全書. Hongkong: Chinese University of Hong Kong and Digital Heritage Publishing Ltd. http://erf.sbb.spk-berlin.de/han/SikuQuanshu (Zuletzt aufgerufen: 30.11.2021).

SSKT Shinshaku kanbun taikei 新釈漢文大系. 120 Bde. Tōkyō: Meiji shoin 明治書院, 1960-2014.

\subsection{Bibliografien, Indices und Spezialnachschlagewerke}

Asakura, Haruhiko 朝倉治彦 (1983): Kinsei shuppan kōkoku shūsei 近世出版広告集成: Fukkoku ban 復刻版 (6 Bde.). (Shoshi shomoku shirīzu 書誌書目シリーズ, 11). Tōkyō: Yumani Shobō ゆまに書房.

Asakura, Haruhiko 朝倉治彦 und Higuchi, Hideo 樋口秀雄 (1962): Kyōhō igo - Edo shuppan shomoku 享保以後江戸出版書目: Mikan kokubun shiryō 未刊国文資料: Fukkoku ban 復刻 版: Rinsen Shoten 臨川書店.

Asano, Bunzaburō 朝野文三郎 (1937): Meiji shonen yori nijūnenkan tosho to zasshi 明治初年 より二十年間図書と雑誌. Tōkyō: Senshindō Shojuku 洗心堂書塾.

Geppyō Sha 月評社 (1982): Shuppan geppyō 出版月評 (6 Bde.). Tōkyō: Ryūkei Shosha 龍溪書舎. Gotō, Kenji 後藤憲二 (1990): Kinsei katsujiban zuroku 近世活字版図録. (Nihon shoshigaku taikei 日本書誌学大系, 61). Musashimurayama 武蔵村山: Seishōdō shoten 青裳堂書店.

Hirata, Yumi 平田由美 (1989): Meiji chūki Yomiuri shinbun bungei kankei kiji mokuroku 明治中 期読売新聞文芸関係記事目録 (1 Bd.). Kyōto 京都: Kyōto Daigaku Jinbun Kagaku Kenkyūjo 京都大学人文科学研究所.

Ichiko, Teiji 市古貞次 (1986): Nihon bungaku dai nenpyō 日本文学大年表. Tōkyō: Ōfūsha 桜楓社. Ichiko, Teiji 市古貞次 (1990): Nihon bunka sōgō nenpyō 日本文化総合年表. Tōkyō: Iwanami Shoten 岩波書店.

Ishikawa, Iwao 石川䉷 (1927): „Meiji shoki gesaku nenpyō 明治初期戯作年表“. In: Nihon kindai bungaku no shoshi 日本近代文学の書誌: Meiji hen 明治編 (Hg. Nihon Bungaku Kenkyū Shiryō Kankōkai 日本文学研究資料刊行会; Nihon bungaku kenkyū shiryō sōsho 日本文学研究資料叢書; Tōkyō: Yūseidō Shuppan 有精堂出版, 1982): 1-80.

Iwanami Shoten Henshūbu 岩波書店編集部 (1968): Kindai Nihon sōgō nenpyō 近代日本総合 年表. 3. Aufl. Tōkyō: Iwanami Shoten 岩波書店.

Katō, Tomoyasu 加藤友康, Seno, Seiichirō 瀬野精一郎, Toriumi, Yasushi 鳥海靖 und Maruyama, Yasunari 丸山雍成 (2001): Nihonshi sōgō nenpyō 日本史総合年表. Tōkyō: Yoshikawa Kōbun Kan 吉川弘文館.

Kawase, Kazuma 川瀬一馬 (1933): Kohanpon zuroku 古版本図録. Tōkyō: Isseidō 一誠堂.

Meiji zenki shomoku shūsei 明治前期書目集成 (1971): Kimura, Ki 木村毅 (Hg.): Fukkoku ban 復 刻版 (20 Bde.). Tōkyō: Meiji Bunken 明治文献.

Kracht, Klaus (2000): Japanese thought in the Tokugawa era: A bibliography of Westernlanguage materials. (Izumi, 6). Wiesbaden: Harrassowitz Verlag. 
Kraft, Eva (1982): Japanische Handschriften und Traditionelle Drucke aus der Zeit vor 1868 (3 Bde.). Wiesbaden: Franz Steiner Verlag, 1986.

Kubota, Jun 久保田淳 (1993): Sōmokuji - nenpyō - sakuin 総目次 · 年表 - 索引. (Iwanami kōza Nihon bungaku shi 岩波講座日本文学史, 17). Tōkyō: Iwanami Shoten 岩波書店.

Matsuzaki, Hitoshi 松崎仁, Shiraishi, Teizō 白石悌三 und Taniwaki, Masachika 谷脇理史 (1977): Nenpyō shiryō Kinsei bungaku shi 年表資料近世文学史. Tōkyō: Kasama Shoin 笠間書院.

Meiji Bunka Shiryō Sōsho Kankōkai 明治文化資料叢書刊行会 (Hg.) (1870): Shomoku hen 書目 篇: Daigaku hen 大学編 - Daishikyoku hen 大史局編. (Meiji bunka shiryō sōsho 明治文化 資料叢書, 7): Kazama Shobō 風間書房. Online verfügbar unter info://ndljp/pid/2966140, 1963.

Shomoku hen 書目篇 (1963): Meiji Bunka Shiryō Sōsho Kankōkai 明治文化資料叢書刊行会 (Hg.): Kazama Shobō 風間書房 (Meiji bunka shiryō sōsho 明治文化資料叢書, 8).

Munemasa, Isoo 宗政五十緒 und Wakabayashi, Seiji 若林正治 (1965): Kinsei Kyōto shuppan shiryō 近世京都出版資料. Tōkyō: Nippon Kosho Tsūshin Sha 日本古書通信社.

Murakami, Kanbē 村上勘兵衛, Asakura, Haruhiko 朝倉治彦 und Sakuma, Nobuko 佐久間信子 (1874): Goishin irai Kyōto shinkoku shomoku binran 御維新以来京都新刻書目便覧. (Meiji shoki Santo shinkoku shomoku 明治初期三都新刻書目). Tōkyō: Nippon Kosho Tsūshin Sha 日本古書通信社, 1971.

Naikaku tōkei kyoku 内閣統計局 und Nakamura, Takafusa 中村隆英 (1882-1885): Nihon teikoku Tōkei nenkan 1 日本帝国統計年鑑: 1 (1 Bd.). (Kindai Nihon rekishi tōkei shiryō 近 代日本歷史統計資料, 8). Tōkyō: Tōyō Shorin 東洋書林, 1999.

Odagiri, Hideo 小田切秀雄 (1993): Nihon kindai bungaku nenpyō 日本近代文学年表. Tōkyō: Shōgakukan 小学館.

Ozaki, Kyūya 尾崎久彌 (1927): Edo jidai shōsetsu, kyakuhon, jōruri, zuihitsu, honkoku mono sakuin 江戸時代小説・脚本淨瑠璃・隨筆眽刻物索引. Tōkyō: Shun'yōdō 春陽堂.

Satō, Miyuki 佐藤深雪 (1985): „Nihon koten bungaku hyōron shi nenpyō 日本古典文学評論史 年表“. In: Nihon koten bungaku hyōron shi 日本古典文学評論史 (Hg. Fukui, Teisuke 福井 貞助): 335-366. Tōkyō: Ōfūsha 桜楓社.

Schuessler, Axel (1987): A Dictionary of Early Zhou Chinese. Honolulu: University of Hawai'i Press.

Shibata, Mitsuhiko 柴田光彦 (1978): Taisō zōsho mokuroku to kenkyū 大惣蔵書目録と研究: Kashi hon'ya Ōnoya Sōbē kyū zōsho moku 貸本屋大野屋惣兵衛旧蔵書目 (2 Bde.). (Nihon shoshigaku taikei 日本書誌学大系, 27.1 - 27.2). Musashi Murayama 武蔵村山: Seishōdō shoten 青裳堂書店, 1983.

Shimizu, Shigeru 清水茂 (1967): „Futabatei Shimei sankō bunken mokuroku 二葉亭四迷参考文献 目録“. In: Futabatei Shimei 二葉亭四迷 (Hg. Shimizu, Shigeru 清水茂). (Kindai bungaku kanshō kōza 近代文学鑑賞講座, 1): 400-410. Tōkyō: Kadokawa Shoten 角川書店.

Shōwa Joshi Daigaku Kokubungaku Kenkyūshitsu 昭和女子大学国文学研究室 (1982):

„Shinbun shōsetsu no nenpyō 新聞小説の年表“. In: Nihon kindai bungaku no shoshi 日本 近代文学の書誌: Meiji hen 明治編 (Hg. Nihon Bungaku Kenkyū Shiryō Kankōkai 日本文学 研究資料刊行会). (Nihon bungaku kenkyū shiryō sōsho 日本文学研究資料叢書): 201-234. Tōkyō: Yūseidō Shuppan 有精堂出版.

Suzuki, Eiji 鈴木英治 und Kirisaka, Yoshiko 切坂美子 (2011): „Bakumatsu ni sakusei - kankō sareta wakoku yōsho 幕末に作成・刊行された和刻洋書: Nagasaki ban no sozai to kōzō 長崎版の素材と構造“. In: Bunkazai jōhō gaku kenkyū 文化財情報学研究 ((8) 2011.3): 47-57. 
Tajibi, Ikuo 多治比郁夫 und Nakano, Mitsutoshi 中野三敏 (1990): Kinsei katsujiban mokuroku 近世活字版目録. (Nihon shoshigaku taikei 日本書誌学大系, 50). Musashimurayama 武蔵 村山: Seishōdō shoten 青裳堂書店.

Takaichi, Yoshio 高市慶雄 (1932): Meiji bunken mokuroku 明治文献目録. Tōkyō: Nihon Hyōron Sha 日本評論社.

Tōkyō Daigaku Fuzoku Toshokan Jōhō Kiban Sentā 東京大学附属図書館・情報基盤センター (no date): Mori Ōgai Bunko 森鴎外文庫: Kakiirehon gazō dētā bēsu 書入本画像データー ベース. Online verfügbar unter http://rarebook.dl.itc.u-tokyo.ac.jp/ogai/index.html.

Shoseki Sōmokuroku 書籍総目録: Fukkoku ban 復刻版 (8 Bde.) (1975) (8 Bde.). Tōkyō: Yumani Shobōゆまに書房.

Verwayen, Frans B. (1993): „Tokugawa Translations of Dutch Legal Texts“ (LIII.3 (Autumn 1993): 335-358.

Waseda Daigaku Toshokan shozō Futabatei Shimei shiryō 早稲田大学図書館所蔵二葉亭四迷 資料 (1965): Waseda Daigaku Toshokan 早稲田大学図書館 (Hg.): Mokuroku - kaisetsu honkoku 目録・解説・翻刻: (Waseda Daigaku Toshokan kiyō 早稲田大学図書館紀要, Bessatsu dai 1 別冊第1).

Yamaguchi, Takemi 山口武美 (1980): Meiji zenki gesakubon shomoku 明治前期戯作本書目. (Nihon shoshigaku taikei 日本書誌学大系, 10). Musashi Murayama 武蔵村山: Seishōdō shoten 青裳堂書店.

Yamazaki, Fumoto 山崎麓 (1929): Nihon shōsetsu shomoku nenpyō 日本小説書目年表: Kaitei 改訂. 111. Aufl. (Shoshi shomoku shirīzu 書誌書目シリーズ, 6). Tōkyō: Yumani Shobō ゆまに書房, 1977.

Yayoshi, Mitsunaga 弥吉光長 (1982): Shoshi to tosho hyōron 書誌と図書評論. Tōkyō: Nichigai Asōshiētsu Tōkyō 日外アソシエーツ東京.

Yayoshi, Mitsunaga 弥吉光長 (1989): Mikan shiryō ni yoru Nihon shuppan bunka 未刊史料に よる日本出版文化: Dai 4 kan 第4巻: Edo shuppan shi - bungei shakai teki ketsuron 江戸 出版史-文芸社会学的結論. (Shoshi shomoku shirīzu 書誌書目シリーズ, 26): Yumani Shobōゆまに書房.

Yayoshi, Mitsunaga 弥吉光長 (1993): Mikan shiryō ni yoru Nihon shuppan bunka 未刊史料に よる日本出版文化: Dai 8 kan 第8巻: Bakumatsu Meiji shuppan shiryō 幕末明治出版史料. (Shoshi shomoku shirīzu 書誌書目シリーズ, 26): Yumani Shobō ゆまに書房.

Yoshida, Seiichi 吉田精一 (1955): Hyōron nenpyō 評論年表. (Gendai bungaku ron taikei 現代文 学論大系, 8). Tōkyō: Kawade Shobō 河出書房.

Yoshida, Seiichi 吉田精一 (1971): „Kindai bungaku hyōron nenpyō 近代文学評論年表“. In: Kindai bungaku hyōron nenpyō 近代文学評論年表 (Hg. Satō, Masaru 佐藤勝). (Kindai bungaku hyōron taikei 近代文学評論大系, 10): 4-96. Tōkyō: Kadokawa Shoten 角川書店.

\subsection{Korpus-Kandidaten und Korpus}

»Korpus-Kandidaten« meint hier die Gruppe jener Literaturtheorien der Jahre 1850 bis 1890, aus welchen die Texte des »Korpus« (die Hauptgegenstände) der vorliegenden Abhandlung ausgewählt wurden. Aus Platzgründen werden nicht alle 450 Kandidaten hier aufgelistet. Die mit (Jahr)*: gekennzeichneten Texte wurden in den Korpus aufgenommen. 
[Anonymus] (1868): „Kōgisho hōsoku an 広議所法則案“. In: Kensei hen 憲政篇 (Hg. Yoshino, Sakuzō 吉野作造; Meiji bunka zenshū 明治文化全集, 4; Tōkyō: Nihon Hyōron Sha 日本評 論社, 1928): 3-4.

[Anonymus] (1868): „Kōgisho hōsoku an 広議所法則案“. In: Kensei hen 憲政篇. Fukkoku ban 復刻版 (Hg. Meiji Bunka Kenkyūkai 明治文化研究会; Meiji bunka zenshū 明治文化全集, 1; Tōkyō: Nihon Hyōron Sha 日本評論社, 1992-1993): 3-4.

[Anonymus] (1878): „Kyojitsu ron 虚実論“. In: Nanaichi zappō 七一雑報 (3.44 (1. Nov. 1878): 1-2.

[Anonymus] (1889): „Edatarō rakochō wo jikkō su 枝太郎裸胡蝶を実行す“. In: Yomiuri shinbun 読売新聞, 25.01.1889: 3.

[Anonymus] (1889): „Ichikawa Danjūrō 市川団十郎“. In: Jiji shinpō 時事新報 (2244), 30.03.1889: 2 .

[Anonymus] (1890): „Bungaku sekai no kinkyō 文学世界の近況“. Original in Chōya shinbun 朝 野新聞,27. Feb. 1890. In: Meiji ki 1 明治期 I (Hgg. Yoshida, Seiichi 吉田精一 und Asai, Kiyoshi 浅井清; Kindai bungaku hyōron taikei 近代文学評論大系, 1; Tōkyō: Kadokawa Shoten 角川書店, 1971): 98-99.

Ariga, Nagao 有賀長雄 (1885): Bungaku ron 文学論. (Bungaku sōsho 文學叢書, 1). Tōkyō: Maruzen Shōsha Shoten 丸善商社書店.

Asano, Kyōfu 浅野狂夫 (1885): „Shiika wa bunmei to heishin sezu 詩歌は文明と併進せず“. In: Yomiuri shinbun 読売新聞, 10.05.1885.

Baitei, Kinga 梅亭金黛 (1857-1863): Myōchikurin Shichi henjin 妙竹林七偏人 (5 Bde.). Edo 江 戸: Ōkawa Jōkichi 大川錠吉.

Baitei, Kinga 梅亭金倪 (1863): Myōchikurin Shichi henjin 妙竹林七偏人. (5). Edo 江戸: Ōkawa Jōkichi 大川錠吉, 1863.

Chiaki, Suetaka 千秋季隆 (1868): Kagurauta hyōshaku 神楽歌評釋: Kokubun hyōshaku 國文評 釋. Tōkyō: Tōkyō senmon gakkō shuppan bu 東京專門學校出版部.

Fujita, Tōko 藤田東湖 (1868): Tōko shishō 東湖詩鈔 [unbekannt]: Muguraya 葎屋.

Fukuchi, Ōchi 福地桜痴 (1875): „Bun ron 文論“. In: Tōkyō nichinichi shinbun 東京日日新聞 (Nr. 1109 (29. Aug. 1875).

Fukuchi, Ōchi 福地桜痴 (1875): „Bunron 文論“. In: Meiji ki 1 明治期 I (Hgg. Yoshida, Seiichi 吉田精一 und Asai, Kiyoshi 浅井清; Kindai bungaku hyōron taikei 近代文学評論大 系, 1; Tōkyō: Kadokawa Shoten 角川書店, 1971): 13-14.

Fukuchi, Ōchi 福地桜痴 (1875): „Nihon bungaku no fushin wo tanzu 日本文学の不振を嘆ず“. In: Tōkyō nichinichi shinbun 東京日日新聞: 342-343.

Fukuchi, Ōchi 福地桜痴 (1883): „Seiji ni kansuru haishi shōsetsu no hitsuyō naru wo ronzu 政事に関する稗史小説の必要なるを論ず“. In: E'iri jiyū shinbun 絵入自由新聞 (26. - 29. Aug. 1883): 20-22.

Fukuchi, Ōchi 福地桜痴 (1883): „Waga kuni ni jiyū no shushi wo hashoku suru ichi shudan wa haishi gikyoku nado no rui wo kairyō suru ni ari 我国二自由ノ種子ヨ播殖スル一手段八稗 史戯曲等ノ類习改良スルニ在リ “. In: Meiji ki 1 明治期 I (Hgg. Yoshida, Seiichi 吉田精一 und Asai, Kiyoshi 浅井清; Kindai bungaku hyōron taikei 近代文学評論大系, 1; Tōkyō: Kadokawa Shoten 角川書店, 1971): 15-19.

Fukuchi, Ōchi 福地桜痴 „Bunshōron 文章論“. In: Tōkyō nichinichi shinbun 東京日日新聞 (2834 (14. Mai 1881) - 2835 (24. Mai 1881): 4; 4.

Fukutomi, Yasunori 福富恭礼 (1884): Genkō hōritsu kisoku rui zen 現行法律規則類全. Tōkyō: Kōdōkan 広道館, 1884-85.

Fukuzawa, Yukichi 福沢諭吉 (1867): Seiyō tabi annai 西洋旅案内. Tōkyō: Keiō Gijuku Kyoku 慶応義塾局, 1867. 
Fukuzawa, Yukichi 福沢諭吉 (1869): „Gihan torishimari kankei bunsho 儀版取締関係文書“. In: Fukuzawa Yukichi zenshū 福沢諭吉全集: Dai 19 kan 第 19 巻. Hg. Keiō Gijuku 慶応義塾): 441-478.

Fukuzawa, Yukichi 福沢諭吉 (1883): „Bungaku kaiin ni tsugu 文学会員に告ぐ“. In: Fukuzawa Yukichi zenshū 福沢諭吉全集: 363-365.

Fukuzawa, Yukichi 福沢諭吉 (1898): „Kaei tsūgo 華英通語“. In: Fukuzawa zenshū 福澤全集: 81-288.

Fukuzawa, Yukichi 福沢諭吉 und Kuroda, Yukijirō 黒田行次郎 (1868): Zōho wage Seiyō jijō 増補和解 西洋事情 (4 Bde.). Kōto 皇都: Hayashi Yoshibē 林芳兵衛.

Futabatei, Shimei 二葉亭四迷 (1886) *: „Shōsetsu sōron 小説総論“. In: Bungaku geijutsu hen 文学芸術篇 (Hg. Kimura, Ki 木村毅; Meiji bunka zenshū 明治文化全集, 12; Tōkyō: Nihon Hyōron Sha 日本評論社 (1928): 538-541.

Futabatei, Shimei 二葉亭四迷 (1887-1888): „Ukigumo 浮雲“. In: Futabatei Shimei shū二葉亭 四迷集 (Hgg. Tanaka, Yasutaka 田中保隆, Hata, Yūzō 畑有三 und Yasui, Ryōhei 安井亮平; Nihon kindai bungaku taikei 日本近代文学大系 4; Tōkyō: Kadokawa Shoten 角川書店, 1971;): 37-220.

Futabatei, Shimei 二葉亭四迷 (1887-1891): Ukigumo 浮雲 (3 Bde.). Tōkyō: Kinkōdō Shoseki 金港堂書籍.

Futabatei, Shimei 二葉亭四迷 (1888): „Gakujutsu to bijutsu no sabetsu 学術と美術の差別“. In: Kokumin No Tomo 国民之友 (19 (Apr. 1888): 7-11.

Futabatei, Shimei 二葉亭四迷 (1889) *: „Ochiba no hakiyose 落葉のはきよせ: Futakago me二 籠め“. In: Futabatei Shimei - Saganoya Omuro shū二葉亭四迷・峵峨の屋おむろ集 $(\mathrm{Hg}$. Nakamura, Mitsuo 中村光夫; Meiji bungaku zenshū 明治文学全集, 17; Tōkyō: Chikuma Shobō 筑摩書房 (1971): 134-166.

Futabatei, Shimei 二葉亭四迷 (1889): „Bungaku no honshoku oyobi heimin to bungaku to no kankei 文学の本色及平民と文学との関係: [1]“. Ro Doburoryūbofu cho 露ドブロリウボフ 著 - Hasegawa Tatsunosuke iyaku 長谷川辰之助意訳. In: Kokumin No Tomo 国民之友, 4 (47 (Apr. 1889): 12-17.

Gangan hōshi 蟋々法史 (1889): „Dokutoru Ryūka kei e ドクトル柳下恵へ“. In: Yomiuri shinbun 読売新聞, 17.01.1889: 3.

Ganryōsei 雁陵生 (1890): „Bungaku gokusui no gen'in oyobi sono kyōseihō 文学極衰の原因及 び其矯正法“. In: Jogaku Zasshi 女学雑誌 (195 (Jan. 1890).

Gūhyō Kintai meika bun shō 偶評今體名家文抄 (1877): Doi, Kōka 土居光華 (Hg.): Kan 2-3 巻2-3. Kōfu 甲府: Naitō Den'emon 内藤傳右衛門.

Hagiwara, Hiromichi 萩原広道 (1854) *: Genji monogatari hyōshaku 源氏物語評釈 (14 Bde.). Ōsaka-fu 大阪府: Bun'ei dō 文永堂.

Hagiwara, Hiromichi 萩原広道, Motoori, Toyokai 本居豊頴, Kimura, Shōji 木村正辞 und Inoue, Yorikuni 井上頼图 (1854): „Kōsei yakuchū Genji monogatari hyōshaku 校正訳注源氏物語 評釈: Sōron 総論“. In: Kokubun chūshaku zensho 国文註釈全書: Dai 12 hen 第12編: Genji monogatari hyōshaku 源氏物語評釈 (Hg. Muromatsu, Iwao 室松岩雄; Kokubun chūshaku zensho 国文註釈全書, 12; Ōsaka 大阪: Kōgaku Shoin 皇学書院, 1926): 1-72.

Harada, Kyokusai 原田曲斎 (1859) *: Jōkyō shiki kaiin roku 貞享式海印録 (6 Bde.). Kyōto 京都 und Ōsaka 大阪: Tachibanaya Jihē 橘屋治兵衛 u.a.

Hirose, Tansō 広瀬淡空 (1883): „Tansō shiwa 淡空詩話“. In: Kinsei bungakuron shū 近世文学 論集 (Hg. Nakamura, Yukihiko 中村幸彦; Nihon koten bungaku taikei 日本古典文学大系, 94; Tōkyō: Iwanami Shoten 岩波書店, 1966): 349-405. 
Hirose, Tansō 広瀬淡空 und Hirose, Seison 広瀬青邨 (1883) *: Tansō shiwa 淡空詩話 (2 Bde.). Tōkyō fu 東京府: Hakubunsha 博聞社, 1883.

Hisamatsu, Teikō 久松定弘 (1887): Doitsu Gikyoku tai’i 独逸戯曲大意 (1 Bd.). Tōkyō fu 東京府: Hisamatsu Teikō 久松定弘, 1887.

Igarashi, Atsuyoshi 五十嵐篤好 (1863): Yutsu tsumagushi 湯津爪櫛. Kanazawa 金沢: Chikaokaya 近岡屋太兵衛.

Ikebukuro, Seifū 池袋清風 (1889): „Shintai shi hihyō 新体詩批評: 1一“. In: Kokumin no tomo 国民之友: Fukusei ban 複製版. Meiji bunken han 明治文献版 (Hgg. Meiji Bunken Shiryō Kankōkai 明治文献資料刊行会 und Fujiwara, Masato 藤原正人; 29 Bde.; Tōkyō: Meiji Bunken 明治文献, 1966-1968): 52-53.

Ikebukuro, Seifū 池袋清風 (1889): „Shintai shishō hihyō 新体詩抄批評: 2 二“. In: Kokumin no tomo 国民之友: Fukusei ban 複製版. Meiji bunken han 明治文献版 (Hgg. Meiji Bunken Shiryō Kankōkai 明治文献資料刊行会 und Fujiwara, Masato 藤原正人; 29 Bde.; Tōkyō: Meiji Bunken 明治文献, 1966-1968): 111-113.

Ikebukuro, Seifū 池袋清風 (1889): „Shintai shishō hihyō 新体詩抄批評: 3 三“. In: Kokumin no tomo 国民之友: Fukusei ban 複製版. Meiji bunken han 明治文献版 (Hgg. Meiji Bunken Shiryō Kankōkai 明治文献資料刊行会 und Fujiwara, Masato 藤原正人; 29 Bde.; Tōkyō: Meiji Bunken 明治文献. 1966-1968): 170-172.

Imamura, Nagayoshi 今村長善 (1889): Bunshō tetsugaku 文章哲学: Philosophy of Composition. Tōkyō: Imamura Nagayoshi 今村長善, 1889.

Inoue, Fumio 井上文雄 (1858): Ise no ietsuto 伊勢の家裏. Nagoya 名古屋: Bunkōdō 文光堂. Inoue, Tetsujirō 井上哲次郎 (1882): Shinri shinsetsu 心理新説: Beiin cho 倍因 (ベイン) 著; Inoue Tetsujirō shō yaku 井上哲次郎抄訳; Ōtsuki Fumihiko kō 大槻文彦校 (2 Bde.). Tōkyō: Aoki Hosei 青木輔清, 1882.

Inoue, Tetsujirō 井上哲次郎 (1884) *: Sonken shishō 巽軒詩鈔 (2 Bde.). Tōkyō: Sakagami Hanshichi 阪上半七.

Inoue, Tetsujirō 井上哲次郎 (1891): Naichi zakkyo ron 内地雑居論 (2 Bde.). Tōkyō: Tetsugaku Shoin 哲学書院, 1891.

Inoue, Tetsujirō 井上哲次郎 (1897): ,Nihon bungaku no kako oyobi shōrai 日本文学の過去及 び将来“. In: Sonken ronbun 巽軒論文 (Hg. Inoue, Tetsujirō 井上哲次郎 (2 Bde.; Tōkyō: Fuzanbō 冨山房, 1901-1902): 80-119.

Inoue, Tetsujirō 井上哲次郎 und Ariga, Nagao 有賀長雄 (1881): Tetsugaku jỉi 哲学字彙. Tōkyō: Tōkyō Daigaku Sangakubu 東京大学三学部.

Inoue, Tetsujirō 井上哲次郎 und Ariga, Nagao 有賀長雄 (1884): Tetsugaku ji'i 哲学字彙. Tōkyō: Tōkyō Daigaku Gogen 東京大学御原, 1884.

Ishibashi, Ningetsu 石橋忍月 (1887): „Imo to se kagami wo yomu 妹と背鏡を読む“. In: Jogaku zasshi 女学雑誌 (23 (Jan.15, 22, 29): 255-259.

Ishibashi, Ningetsu 石橋忍月 (1887): „Ukigumo no hōhen 浮雲の褒貶“. In: Jogaku zasshi 女学 雑誌, 23 (Sept. 3, 17; Okt. 8, 15): 259-265.

Ishibashi, Ningetsu 石橋忍月 (1888): „Kyūsōō no Shibun hyōhin 鳩巣翁の詩文評品: Dai 1, Shi 第一、詩“. In: Shuppan geppyō 出版月評, 4 (15 (25. Okt. 1888): 10-12.

Ishibashi, Ningetsu 石橋忍月 (1888): „Natsu kotachi 夏木たち“. In: Kokumin no tomo 国民之 友, 3 (29 (Sept. 1888): 39.

Ishibashi, Ningetsu 石橋忍月 (1888): „Ukigumo dainihen no homeotoshi 浮雲第二篇の褒貶“. Original in: Jogaku zasshi 女学雑誌 (März 3, 10, 17). In: Ishibashi Ningetsu zenshū 石橋忍 月全集 3 (Yamamoto, Kenkichi 山本健吉, Inagaki, Tatsurō 稲垣達郎 und Odagiri, Susumu 小田切進, Hgg.; Tōkyō: Yagi shoten 八木書店, 1996): 17-22. 
Ishibashi, Ningetsu 石橋忍月 (1889): „“Kuraku” to “Oborozukiyo” no hikaku 『苦楽』と『朧 月夜』の比較“. In: Kokumin No Tomo 国民之友, 5 (55 (Juli 1889): 33-35.

Ishibashi, Ningetsu 石橋忍月 (1889): „Bungaku hyōron Shigarami zōshi 文学評論柵草屾紙“. In: Kokumin no tomo 国民之友, 5 (67): 36.

Ishibashi, Ningetsu 石橋忍月 (1889): „Dokutoru Ryūka kei ドクトル柳下恵“. In: Yomiuri shinbun 読売新聞 (17), 01. 01.1889.

Ishibashi, Ningetsu 石橋忍月 (1889): ,Jiji shinpō to Jogaku zasshi ni shissu 時事新報と女学雑 誌に質す“. In: Kokumin no tomo 国民之友, 4 (48 (Apr. 1889): 33.

Ishibashi, Ningetsu 石橋忍月 (1889): ,Jogaku zasshi shasetsu “Shōsetsu, shōsetsuka” 女学雑 誌社説「小説、小説家」“. In: Kokumin no tomo 国民之友, 5 (62 (Sept. 1889): 36.

Ishibashi, Ningetsu 石橋忍月 (1889): „Kōson shi no „Muratake“筀村氏の「むら竹」“. In: Ishibashi Ningetsu zenshū 石橋忍月全集 3 (Yamamoto, Kenkichi 山本健吉, Inagaki, Tatsurō 稲垣達郎 und Odagiri, Susumu 小田切進, Hgg.; Tōkyō: Yagi shoten 八木書店, 1996): 80-81.

Ishibashi, Ningetsu 石橋忍月 (1889): „Resshingu ron レッシング論“. In: Ishibashi Ningetsu zenshū 石橋忍月全集 3 (Yamamoto, Kenkichi 山本健吉, Inagaki, Tatsurō 稲垣達郎 und Odagiri, Susumu 小田切進, Hgg.; Tōkyō: Yagi shoten 八木書店, 1996): 60-64.

Ishibashi, Ningetsu 石橋忍月 (1889): „Shijin to gairaibutsu 詩人と外来物“. In: Kokumin no tomo 国民之友, 5 (62 (Sept. 1889): 24.

Ishibashi, Ningetsu 石橋忍月 (1889): „Shincho hyakushu no “Irozange” 新著百種の「色慛 悔」“. In: Kokumin no tomo 国民之友, 23 (1889, Apr. 22, Mai 2): 270-272.

Ishibashi, Ningetsu 石橋忍月 (1889): „Shomoku jisshu 書目十種“. In: Kokumin no tomo 国民 之友 (48): 1.

Ishibashi, Ningetsu 石橋忍月 (1889): „Shōsetsu gunpō Dai ichi 小説群芳第一: Hatsu shigure 初時雨“. In: Ishibashi Ningetsu zenshū 石橋忍月全集 3 (Yamamoto, Kenkichi 山本健吉, Inagaki, Tatsurō 稲垣達郎 und Odagiri, Susumu 小田切進, Hgg.; Tōkyō: Yagi shoten 八木 書店, 1996): 102-103.

Ishibashi, Ningetsu 石橋忍月 (1889): „Shōsetsuka no taigaku 小説家の退学“. In: Jogaku zasshi 女学雑誌, Jan. 1889 (146).

Ishibashi, Ningetsu 石橋忍月 (1889): „Yomiuri shinbun Hito samazama 読売新聞人さまざま“. In: Yomiuri shinbun 読売新聞, 22. 06.1889.

Ishibashi, Ningetsu 石橋忍月 (1890): „Hōchi ibun (Yano Ryūkei shi cho) 報知異文 (矢野龍渓氏 著)“. In: Kokumin no tomo 国民之友, 6 (78 (Apr. 1890): 35.

Ishibashi, Ningetsu 石橋忍月 (1890): „Maihime 舞姫“. In: Kokumin no tomo 国民之友, 6 (72 (Feb. 1890): 38.

Ishibashi, Ningetsu 石橋忍月 (1890): „Muratake Dai jūichi kan むら竹第十一巻“. In: Ishibashi Ningetsu zenshū 石橋忍月全集 3 (Yamamoto, Kenkichi 山本健吉, Inagaki, Tatsurō 稲垣達 郎 und Odagiri, Susumu 小田切進, Hgg.; Tōkyō: Yagi shoten 八木書店, 1996): 110-112.

Ishibashi, Ningetsu 石橋忍月 (1890): „Ōgai no yūgen ron ni kotauru sho 鴎外の幽玄論に答ふ る書“. In: Yamada Bimyō - Ishibashi Ningetsu - Takase Bun'en shū 山田美妙・石橋忍月 • 高瀬文淵集 (Fukuda, Kiyoto 福田清人, Hg.; Tōkyō: Chikuma Shobō 筑摩書房, 1971; MBgZ 23): $276-278$

Ishibashi, Ningetsu 石橋忍月 (1890): „Ōgai no yūgen ron ni kotauru sho 鴎外の幽玄論に答子 る書“. In: Yamada Bimyō - Ishibashi Ningetsu - Takase Bun'en shū 山田美妙 • 石橋忍月 ・ 高瀬文淵集 (Fukuda, Kiyoto 福田清人, Hg.; Tōkyō: Chikuma Shobō 筑摩書房, 1971; MBgZ 23): $276-278$.

Ishibashi, Ningetsu 石橋忍月 (1890): „Shiika no seishin oyobi yojō 詩歌の精神及余情“. In: Kokumin no tomo 国民之友, 6 (69 (3. Jan. 1890): 12-15. 
Ishibashi, Ningetsu 石橋忍月 (1890): „Utakata no ki うたかたの記“. In: Kokumin no tomo 国民 之友, 23 (1890 Okt. 23): 274-276.

Ishibashi, Ningetsu 石橋忍月 (1892) *: „Sō jitsu ron 総実論“. In: Koganemura 黄金村 (Shūho jisshu 聚芳十種, 8; Tōkyō: Shun'yōdō 春陽堂): 141-172.

Ishizuka, Hōkaishi 石塚豊芥子 (1859): Hana no Edo Kabuki nendaiki 花江都歌舞伎年代記: Zokuhen 続編: Fukkoku ban 覆刻版. Tōkyō: Ōtori Shuppan 鳳出版, 1976.

Isogai, Unpō 磯貝雲峯 (1890): „Kan'in ron 姦淫論“. In: Jogaku zasshi 女学雑誌, 1890.01 -.02 (196-198).

Isogai, Unpō 磯貝雲峯 (1890): „Suichinkō wo yomu 酔沈香を読む“. In: Jogaku zasshi 女学雑 誌 (196 (18. Jan. 1890): 4-7.

Isogai, Unpō 磯貝雲峯 und Uu dōjin 烏々道人 (1890): „Sei? Sui? 盛?衰?“. In: Jogaku zasshi 女学雑誌 (196 (18. Jan. 1890): 18-19.

Iwamoto, Yoshiharu 䉷本善治 (1888): „Kan'in no kūki - fujunketsu no kūki 姦淫の空気、不純 潔の空気“. In: Jogaku Zasshi 女学雑誌 (150): 1-7.

Iwamoto, Yoshiharu 敐本善治 (1889): „Joryū shōsetsuka no honshoku 女流小説家の本色“. In: Kirisuto sha hyōron shū キリスト者評論集 (Hgg. Yabu, Teiko 藪禎子, Yoshida, Masanobu 吉田正信 und Izuhara, Takatoshi 出原隆俊; Shin Nihon koten bungaku taikei 新日本古典 文学大系: Meiji hen 明治編, 26; Tōkyō: Iwanami Shoten 岩波書店, 2002): 164-172.

Iwamoto, Yoshiharu 㱟本善治 (1889): „Kokumin no tomo dai 50-gō ni okeru “Bungaku to shizen” wo yomu, wo kindoku su 国民之友第五十号における「文学と自然を読む」、を 謹読す“. In: Jogaku zasshi 女学雑誌 (162 (18. Mai 1889): 15-17.

Iwamoto, Yoshiharu 嚴本善治 (1889): „Kokumin no tomo dai yonjūhachi gō Bungaku to shizen 国民之友第四十八号文学と自然“. In: Jogaku zasshi 女学雑誌 (159 (Apr. 1889): 10-11.

Iwamoto, Yoshiharu 䉷本善治 (1889): „Kokumin no tomo dai yonjūhachi gō Bungaku to shizen 国民之友第四十八号文学と自然“. In: Meiji ki 1 明治期 I (Hgg. Yoshida, Seiichi 吉田精一 und Asai, Kiyoshi 浅井清; Kindai bungaku hyōron taikei 近代文学評論大系, 1; Tōkyō: Kadokawa Shoten 角川書店, 1971): 67-68.

Iwamoto, Yoshiharu 畋本善治 (1889): „Shizen sūhaisha no kotae 自然崇拝者の答“. In: Jogaku zasshi 女学雑誌 (165 (8. Juni 1889): 30.

Iwamoto, Yoshiharu 巌本善治 (1889): „Shōsetsu ronryaku 小説論略: 1: Shōsetsu, shōsetsuka 一小説、小説家“. In: Jogaku zasshi 女学雑誌, Aug. 1889 (177): 1-5.

Iwamoto, Yoshiharu 嚴本善治 (Okt. - 1887): „Shōsetsu ron 小説論 (1) Shōsetsu wo yomu yoshi ashi no koto 小説を読む善悪の事; (2) Shōsetsu no yoshi ashi wo hihyō suru meate no koto 小説の善悪を批評する標準の事; (3)“. In: Jogaku zasshi 女学雑誌 ((1) 82; (2) 83; (3) 84): 1.

Jōno, Saigiku 条野採菊 (1862): Shunshoku koi no somewake 春色恋輏染分解 (5 Bde.). Edo 江戸: Bunrindō 文鱗堂, 1860-1865.

Jōno, Saigiku 条野採菊 (1864): Shunshoku Edo no murasaki 春色江戸紫. (Kōmutei sōsho 香夢 亭叢書, 3). Edo 江戸: Shun'yōdō 春陽堂, 1864-1883.

Jōno, Saigiku 条野採菊 (1865): „Hanagoyomi fūjibumi 花暦封じ文 “. In: Ninjōbon kankōkai [sōsho] 人情本刊行會[叢書] (Hg. Ninjōbon Kankōkai 人情本刊行會 (11 Bde.; Tōkyō: Ninjōbon Kankōkai 人情本刊行會, 1915-1916): 193-194;312.

Jōno, Saigiku 条野採菊 und Somezaki, Enbō 染崎延房 (1873-1881) *: Kinsei kibun 近世紀聞. Tōkyō: Shun'yōdō 春陽堂, 1926.

Kanagaki, Robun 仮名垣魯文 (1860): Kokkei Fuji mōde 滑稽富士詣 (2 Bde.). (Koten bunko 古典 文庫, 162). Tōkyō: Koten Bunko 古典文庫, 1961.

Kanagaki, Robun 仮名垣魯文 (1872) *: „Chosakudō kakiage 著作道書き上げ“. In: Tōkyō nichinichi shinbun 東京日日新聞, Juni 1872. 
Kanagaki, Robun 仮名垣魯文 und Utagawa, Yoshitora 歌川芳虎 (1861) *: Osana etoki bankoku banashi 童絵解万国噺 (4 Bde.). Edo 江戸: Tsujokaya Bunsuke 辻岡屋文助.

Kanagaki, Robun 仮名垣魯文, Fusōkan 総生寛 und Nakamura, Masaaki 中村正明 (1870-76) *: Bankoku kōkai Seiyō dōchū hizakurige 万国航海西洋道中膝栗毛: Fukkoku ban 復刻版 (3 Bde.). (Hizakurige bungei shūsei 膝栗毛文芸集成, 36-38). Tōkyō: Yumani Shobō ゆまに 書房, 2017.

Kanemoto, Masai 金本摩斎 (1869): Rakusandō shishō 楽山堂詩鈔 (2 Bde.). Tōkyō: Sōeidō 宋栄堂.

Kasai, Kiyoshi 葛西清 (1868): Danran shū 団欒集 (2 Bde.). Tōkyō: Kinkadō 錦花堂.

Katonbō 嘉遯坊 (1889): „Hadaka de dōchū naru mono ka 裸で道中なるものか“. In: Yomiuri shinbun 読売新聞, 13.01.1889: 3.

Kikuchi, Dairoku 菊池大麓 (1884-1885): „Shūji oyobi kabun 修辞及華文“. In: Hyakka zensho 百科全書 (Kikuchi, Dairoku 菊池大麓, Chambers, William, Chambers, Robert und Monbushō 文部省, Hgg.; Tōkyō: Maruzen Shōsha Shoten 丸善商社書店): 1083-1130.

Kimura, Mokurō 木村黙老 (1849) *: „Kokuji shōsetsu tsū 国字小説通“. In: Zoku enseki jisshu 続燕石十種: Dai 1 kan 第1巻 (Hgg. Iwamoto, Kattōshi 岩本活東子 und Hirotani, Yūtarō 広 谷雄太郎; Tōkyō: Hirotani Kokusho Kankōkai 広谷国書刊行会, 1927): 246-257.

Kimura, Mokurō 木村黙老 (1849): „Keisetsu gesakusha kō 京摂戯作者考“. In: Zoku enseki jisshu 続燕石十種: Dai 1 kan 第1巻 (Iwamoto, Kattōshi 岩本活東子 und Hirotani, Yūtarō 広 谷雄太郎, Hgg.; Zoku enseki jisshu 続燕石十種, 1; Tōkyō: Hirotani Kokusho Kankōkai 広 谷国書刊行会, 1927): 258-283.

Kimura, Mokurō 木村黙老 (1849): „Kokuji shōsetsu tsū 国字小説通“. In: Zoku enseki jisshu 続 燕石十種: Dai 1 kan 第1巻 (Iwamoto, Kattōshi 岩本活東子 und Hirotani, Yūtarō 広谷雄太 郎, Hgg.; Zoku enseki jisshu 続燕石十種, 1; Tōkyō: Hirotani Kokusho Kankōkai 広谷国書 刊行会, 1927): 246-257.

Kinoshita, Tōichirō 木下東一郎 (1888): Kanri chosha shosei yūshi Hikkei jōrei shū 官吏著者書 生有志必携条例集. Tōkyō: Eisai Shinshi Sha 穎才新誌社.

Kitamura, Tōkoku 北村透谷 (1890): „Tōsei bungaku no shio moyō 当世文学の潮摸様“. In: Meiji ki 1 明治期 I (Hgg. Yoshida, Seiichi 吉田精一 und Asai, Kiyoshi 浅井清; Kindai bungaku hyōron taikei 近代文学評論大系, 1; Tōkyō: Kadokawa Shoten 角川書店, 1971): 90-92.

Kitamura, Tōkoku 北村透谷 (1893) *: „Jinsei ni aiwataru to wa nan no ii zo 人生に相渉るとは 何の謂ぞ“. In: Meiji ki 1 明治期/ (Hgg. Yoshida, Seiichi 吉田精一 und Asai, Kiyoshi 浅井清; Kindai bungaku hyōron taikei 近代文学評論大系, 1; Tōkyō: Kadokawa Shoten 角川書店, 1971): 256-262.

Kōda, Rohan 幸田露伴 (1890): „Ihara Saikaku 井原西鶴“. In: Kokumin no tomo 国民之友, 6 (83 (Mai 1890): 26.

Kōgisho nisshi 公議所日誌 (1869)*: Tōkyō fu 東京府: Takeguchi Ryūzaburō 竹口龍三郎.

Konakamura, Kiyonori 小中村清矩 (1888): „Shōsetsu to engeki to no kankei 小説と演劇との 関係“. In: Genshaka 現社会 $i$ (1 (Dez. 1888): 175-178.

Konakamura, Kiyonori 小中村清矩 (1890): „Bunshō ron 文章論“. In: Tōkyō gakushi kaiin zasshi 東京学士会院雑誌, 12 (2 (Mrz. 1890): 41-74.

Kurimoto, Jōun 栗本鋤雲 (1869): Hōan jisshu 匏荑十種 (2 Bde.). Tōto 東都: Okadaya Kashichi 岡田屋嘉七, 1873.

Kurimoto, Jōun 栗本鋤雲 (1869): Hōan jisshu 匏菴十種: Enpitsu kibun 鉛筆紀聞. Tōkyō: Hōchisha 報知社, 1892.

Maeda, Toshiyasu 前田利保 (1853): Ami no tsunade 網茜綱手. Ort und Verlag unbekannt. Online verfügbar unter info://ndljp/pid/2536753. 
Maeda, Toshiyasu 前田利保 (1858): „Kadō zuihitsu 歌道随筆“. In: Ryūtaku kō gozuihitsu 竜沢 公御随筆 (Toyama 富山: Katsura Shobō 桂書房, 1994): 29-51.

Maruyama, Michikazu 丸山通一 (1889): „Mori Rintarō kun ni yokoyari wo tei su 森林太郎君に 横槍を呈す“. In: Jogaku zasshi 女学雑誌 (166 (15. Juni 1889): 18-19.

Matsumoto, Keidō 松本奎堂 und Usui, Tatsuyuki 薄井竜之 (1869): Keidō ikō 奎堂遺稿. Karitani chō 刈谷町: Karitani Bunrei Kan 刈谷文礼館.

Mikami, Sanji 三上参次, Takatsu, Kuwasaburō 高津鍬三郎 und Ochiai, Naobumi 落合直文 (1890): Nihon bungaku shi 日本文学史 (2 Bde.). Tōkyō: Kinkōdō Shoseki 金港堂書籍.

Miki, Takeji 三木竹二 (1889): „Seishin no hadaka ni wa komaru 精神の裸には困る“. In: Yomiuri shinbun 読売新聞, 15. 01.1889:3.

Miyajima, Harumatsu 宮島春松 (1879): „Ōshū shōsetsu Teremaku kafuku monogatari 歐洲小 説哲烈禍福譚“. In: Hon’yaku shōsetsu shū 翻訳小説集: 1 (Nakagawa, Hisayasu 中川久定, Minemura, Shizuko 峯村至津子, Akiyama, Nobuko 秋山伸子, Saitō, Mareshi 齋藤希史 und Watanabe, Yoshiyuki 渡辺喜之, Hgg.; Shin Nihon koten bungaku taikei 新日本古典文学大 系: Meiji hen 明治編, 14; Tōkyō: Iwanami Shoten 岩波書店, 2013): 1-142.

Mizugaki, Egao 美図垣笑顔, Keisai, Eisen 渓斎英泉, Ryūkatei, Tanekazu 柳下亭種員 und Ryūsuitei, Tanekiyo 柳水亭種清 (1839-1868) *: Jiraiya gōketsu monogatari 児雷也豪傑譚 (43 Bde.). Edo 江戸: Izumiya Ichibē 和泉屋市兵衛.

Mizugaki, Egao 美図垣笑顔, Keisai, Eisen 渓斎英泉, Ryūkatei, Tanekazu 柳下亭種員 und Ryūsuitei, Tanekiyo 柳水亭種清 (1839-1868): Jiraiya gōketsu monogatari 児雷也豪傑譚 (43 Bde.). Edo 江戸: Izumiya Ichibē 和泉屋市兵衛.

Mori, Ōgai 森鴎外 (03.01.1889): „Igaku no setsu yori idetaru shōsetsu ron 医学の説より出で たる小説論“. In Hyōron 1 評論一 (Ōgai zenshū chosaku hen 鴎外全集著作篇, 16; Tōkyō: Iwanami Shoten 岩波書店, 1953): 1-2.

Mori, Ōgai 森鴎外 (1889) *: „“Bungaku to shizen” wo yomu「文学卜自然」ヨ読ム“. In: Kokumin no tomo 国民之友, 4 (50 (Mai 1889): 18.

Mori, Ōgai 森鴎外 (1889): „Engeki kairyō ronsha no henken ni odoroku 演劇改良論者の偏見に 驚く“. In: Shigarami zōshi しがらみ草紙 (1): 4-8.

Mori, Ōgai 森鴎外 (1889): „Futatabi geki wo ronjite yo no hyōka ni kotau 再び劇を論じて世の 評家に答ふ“. In Hyōron 1 評論一 (Ōgai zenshū chosaku hen 鴎外全集著作篇, 16; Tōkyō: Iwanami Shoten 岩波書店, 1953): 35-60.

Mori, Ōgai 森鴎外 (1889): „Futatabi shizen sūhaisha ni shissu 再び自然崇拝者に質す“. In: Kokumin no tomo 国民之友 (52 (Jun. 1889): 33.

Mori, Ōgai 森鴎外 (1889): „Ima no shoka no shōsetsuron wo yomite 今の諸家の小説論を読み て“. In: Shigarami zōshi しがらみ草紙 (2 (November 1889): 309-330.

Mori, Ōgai 森鴎外 (1890)*: „Ima no hihyōka no shigan 今の批評家の詩眼“. In: Shigarami zōshi しがらみ草紙 (4): 1-26.

Mori, Ōgai 森鴎外 (1890) *: „Meiji 22 nen hihyōka no shigan 明治二十二年批評家の詩眼“. In: Shigarami zōshi しがらみ草紙 (4): 1-27.

Mori, Ōgai 森鴎外 (1890): „Hōchi ibun ni dai su 報知異聞に題す“. In: Shigarami zōshi しがら み草紙 (Apr. 1890): 100-101.

Mori, Ōgai 森鴎外 (1890): „Toyama Masakazu shi no garon wo baku su 外山正一氏ノ画論 ス“. in Hyōron 1 評論一 (Ōgai zenshū chosaku hen 鴎外全集著作篇, 16; Tōkyō: Iwanami Shoten 岩波書店, 1953): 227-305.

Mori, Ōgai 森鴎外 (1891): „Emiru Zora ga botsu risōエミル・ゾラが没理想“. In: Hyōron 2 評 論二 (Ōgai zenshū chosaku hen 鴎外全集著作篇, 17; Tōkyō: Iwanami Shoten 岩波書店, 1953): 119-123. 
Mori, Ōgai 森鴎外 (1891): „Waseda bunbaku no botsu risō 早稲田文学の没理想“. In: Meiji ki 1 明治期 I (Hgg. Yoshida, Seiichi 吉田精一 und Asai, Kiyoshi 浅井清; Kindai bungaku hyōron taikei 近代文学評論大系, 1; Tōkyō: Kadokawa Shoten 角川書店, 1971): 377-384.

Mori, Ōgai 森鴎外 und Ōmura, Seigai 大村西崖 (1899): Shinbi kōryō 審美綱領 (2 Bde.). Tōkyō: Shun'yōdō 春陽堂, 1899.

Mori, Tatsuyuki 森立之 (1878) *: Bunshō kihan kōkai 文章軌範講解. 2. Aufl. Kōfu 甲府: Onkodō 温故堂, 1879-1881.

Morita, Shiken (1887): „Shīka bunshō no shin’in 詩歌文章の神韵“. In: Kokumin no Tomo 国民 之友, 1 (13 (Dez. 1887): 34.

Morita, Shiken 森田思軒 (1889): „Konnichi no bungakusha 今日の文学者“. In: Kokumin no tomo 国民之友, 4 (48 (Apr. 1889): 11.

Morita, Shiken 森田思軒 (1889): „Konnichi no bungakusha 今日の文学者“. In: Meiji ki 1 明治 期 I (Hgg. Yoshida, Seiichi 吉田精一 und Asai, Kiyoshi 浅井清; Kindai bungaku hyōron taikei 近代文学評論大系, 1; Tōkyō: Kadokawa Shoten 角川書店, 1971): 59-61.

Mozume, Takami 物集高見 (1886): Genbun itchi 言文一致. Tōkyō: Hirao Shizō 平尾氏蔵, 1886.

Mui, Shinnin 無位真人 (1885): „Nihon jōshi no kairyō wo nozomu 日本情史の改良を望む“. In: Jiyū no tomoshibi 自由燈 (19-20 (Aug. 1885): 7-9.

Murakami, Kō 村上剛 (1852) *: „Bussandō shishō 仏山堂詩鈔“. In: Nihon kanshi 日本漢詩: Shishū 詩集: Dai 15 kan 第15巻 (Hg. Fujikawa, Hideo 富士川英郎; Tōkyō: Kyūko Shoin 波 古書院, 1989): 409-578.

Muro, Kyūsō 室鳩巣 (1732): „Sundai zatsuwa 駿台雑話“. In: Nihon rinri ihen 日本倫理彙編: Shushi gakuha no bu 朱子学派の部: jō 上 (Inoue, Tetsujirō 井上哲次郎 und Kanie, Yoshimaru 蟹江義丸, Hgg.; Nihon rinri ihen 日本倫理彙編, 7; Tōkyō: Ikuseikai 育成会, 1902): 81-309.

Mutobe, Yoshika 六人部是香 (1861) *: Chōka tamagoto 長歌玉琴. Ort und Verlag unbekannt, 1861.

Nagano, Takunojō 長野卓之允 (1869): „Zeisho wo yaku no gi 贅書ヨ焼クノ議“. In: Kanpan Gian roku 官版議案録. in Meiji bunka zenshū 1 明治文化全集 1 (Tōkyō: Nihon Hyōron Sha 日本評論社, 1967): 156.

Nakae, Chōmin 中江兆民 (1888): „Bungaku shumi ron no ōen 文学趣味論の応援“. In: Kokumin no tomo 国民之友, 2 (17 (Mrz. 1888): 24.

Nakae, Chōmin 中江兆民 (1888): „Bunshō no myō wa shakai no kyokuchi wo ugatsu ni ari 文章 ノ妙八社会ノ極致习穿ツニアリ “. In: Kokumin no tomo 国民之友, 2 (18 (März 1888): 23.

Nakae, Chōmin 中江兆民 (1894): Dōtokugaku dai genron 道徳学大原論 (Rinrigaku sankō sho 倫理学参考書). Tōkyō: Ichinisan Kan 二二三館, 1894.

Nakajima, Hirotari 中島広足 (1859): „Yamato uta shosetsu 倭歌諸説“. Shiraishi, Yoshio 白石 良夫: „Nakajima Hirotari “Yamato uta shosetsu” honkoku 中島広足『倭歌諸説』翻刻“. In: Bunken tankyū 文獻探究 (9 (1981-12): 10-18.

Nakamura, Masanao 中村正直 (1876): „Insho wo funki (yaki sutsuru) suru jippō 淫書 7 焚毀又 ル十法“. In: Tōkei shinpō 東京新報 (1), 11. 12.1876: 1a-3b.

Nakamura, Masanao 中村正直 (1876): „Shōsetsu (gesakubon) wo zōsuru no shigai 小説ᄏ蔵 スルノ四害“. In: Tōkei shinpō 東京新報, 11. 12.1876: 1a-1b.

Nakamura, Masanao 中村正直 (1881) *: „Bunshō kihan kōkai jo 文章軌範講解序“. In: Keiu sensei shi bun gūshō 敬宇先生詩文偶抄 (Hg. Matsumura, Misao 松村操; Tōkyō: Usagiya Makoto 兔屋誠): 55-56.

Nakamura, Masanao 中村正直 (1883): „Futatabi Inoue Sonken kun ni sho su 復井上巽軒君書“. In: Tōyō gakugei zasshi 東洋學藝雜誌 (19): 512-514. 
Nakamura, Masanao 中村正直 (1883): „Kangaku wa sutsuru bekarazaru no ron 漢学不可廃論 “. In: Keiu Nakamura sensei enzetsu shū 敬宇中村先生演説集 (Hg. Kibira, Yuzuru 木平譲): 103-130.

Nakamura, Masanao 中村正直 (1888): „Kangaku wo osamuru kufū wo ronzu 漢学习治ムル工 夫ヨ論ズ“. In: Keiu Nakamura sensei enzetsu shū 敬宇中村先生演説集 (Hg. Kibira, Yuzuru 木平譲): 50-54.

Nakamura, Masanao 中村正直 (1903): „Gaku no heiso wo ronzu 論学弊疏“. In: Keiu bunshū 1 敬宇文集一 (Tōkyō: Yoshikawa Kōbun Kan 吉川弘文館): 1a-4b.

Nakamura, Masanao 中村正直 (1926) *: „Keiu shishū 敬宇詩集“. In: Shishū Nihon kanshi 詩集 日本漢詩Dai 18 kan 第18巻 (Hgg. Fujikawa, Hideo 富士川英郎, Matsushita, Tadashi 松下 忠 und Sano, Masami 佐野正巳; Tōkyō: Kyūko Shoin 波古書院, 1988): 431-538.

Namagusa bōzu 生臭坊主 (1889): „Rakochō ni tsuite Bimyō dono e no gochūmon 裸胡蝶に付 て美妙殿へ御注文“. In: Yomiuri shinbun 読売新聞, 11.01.1889: 3.

Nandarō shujin 何だ楼主人 (1889): „Dai ni rakochō 第二裸胡蝶“. In: Yomiuri shinbun 読売新 聞, 17.02.1889: 3.

Narushima, Ryūhoku 成島柳北 (1877): „Kagetsu shinshi daigen 花月新誌題言“. In: Narushima Ryūhoku - Hattori Bushō - Kurimoto Jōun shū 成島柳北・服部撫松・栗本鋤雲集 $(\mathrm{Hg}$.

Shioda, Ryōhei 塩田良平, Meiji bungaku zenshū 明治文学全集, 4; Tōkyō: Chikuma Shobō 筑摩書房, 5. Aufl. 1989): 83.

Nishi, Amane 西周 (1870-1872) *: „Hyakugaku renkan 百学連環“. In: Hyakugaku renkan - 百学 連環 - Hyaku'ichi shinron 百一新論 - Seimei hatsu'un 生性発蕰: Fukkoku ban 復刻版 (Hg. Kindai Nihon Shakaigaku Shi Sōsho Henshū linkai 近代日本社会学史叢書編集委員会, 2007): 11-69.

Nishi, Amane 西周 (1870-1872): „Hyakugaku renkan 百学連環“. In: Nishi Amane zenshū 4 西周 全集 4. (Hg. Ōkubo, Toshiaki 大久保利謙; Tōkyō: Shūkō Shobō 宗高書房, 1981): 9-294.

Nishi, Amane 西周 (1874) *: „Chisetsu 知説: Dai 5 第五“. In: Meiroku zasshi 明六雑誌 (25 (Dez. 1874): 1.

Nishi, Amane 西周 (1884): „Bunshō ron wo yomu 文章論ᄏ読么“. In: Meiji keimō shisō shū 明 治啓蒙思想集 (Hg. Ōkubo, Toshiaki 大久保利謙; Meiji bungaku zenshū 明治文学全集 3, 6. Aufl. Tōkyō: Chikuma Shobō 筑摩書房, 1989): 229-231.

Nishimura, Shigeki 西村茂樹 (1884): „Bunshō ron 文章論“. In: Tōkyō gakushi kaiin zasshi 東 京学士会院雑誌 (Sept. 1884): 1-15.

Nishimura, Shigeki 西村茂樹 (1888): „Nihon no bungaku 日本の文学“. Nijū ichi nen sangatsu jūichi nichi kōen二十一年三月十一日講演. In: Tōkyō gakushi kaiin zasshi 東京学士会院雑 誌, 10 (2): 75-95.

Nishizawa, Ippō 西沢一鳳 (1851) *: „Denki sakusho 伝奇作書 (Nishizawa bunko- 西沢文庫)“. In: Engeki Dai 1 演劇第1 (Hg. Kokusho Kankōkai 国書刊行会; Shin gunsho ruijū 新群書類 従, 1; Tōkyō: Kokusho Kankōkai 国書刊行会, 1906-1908): 1-478.

Nishizawa, Ippō 西沢一鳳 (1851): „Kyakushoku yoroku 脚色余録“. In: Engeki Dai 2 演劇第2 (Hg. Kokusho Kankōkai 国書刊行会; Shin gunsho ruijū 新群書類従, 2; Tōkyō: Kokusho Kankōkai 国書刊行会, 1906-1908): 1-272.

Nishizawa, Ippō 西沢一鳳 (1851): „Nishizawa bunko Denki sakusho 西沢文庫伝奇作書“. In: Engeki Dai 1 演劇第1 (Hg. Kokusho Kankōkai 国書刊行会; Shin gunsho ruijū 新群書類従, 1; Tōkyō: Kokusho Kankōkai 国書刊行会, 1906-1908): 1-478.

Obata, Shizan 小畑詩山 (1850): „Shizandō shiwa 詩山堂詩話“. In: Nihon shiwa sōsho 日本詩 話叢書 (10 Bde.; Hgg. Ikeda, Roshū 池田蘆洲 und Kokubu, Takatane 国分高胤; 2. Aufl. (Tōkyō: Ōtori Shuppan 鳳出版, 1972): 465-516. 
Ochiai, Naobumi 落合直文 (1889): „Nihon bungaku no hitsuyō 日本文学の必要“. In: Ochiai Naobumi - Ueda Mannen - Haga Yaichi - Fujioka Sakutarō shū 落合直文・上田万年・ 芳賀矢一 - 藤岡作太郎集 (Hg. Hisamatsu, Sen'ichi 久松潜一; Meiji bungaku zenshū 明治 文学全集 44; Tōkyō: Chikuma Shobōo 筑摩書房, 1968): 3-5.

Okada, Hyōko 岡田水壶 (1854): „Koi no tayori 恋のたより “. In: Kōchū Haibungaku taikei 校註 俳文学大系 1-8; 10-12 (Hgg. Iwaya, Sazanami 嚴谷小波, Itō, Shōu 伊藤松宇 und Hashimoto, Shōka 橋本小舸; Tōkyō: Taihōkaku Shobō 大鳳閣書房, 1929-1930): 391-430.

Okakura, Yoshisaburō 岡倉由三郎 (1890): „Bungaku gairon 文学概論“. In: Kokubungaku 国文 学 (27 (Okt. 1890): 27-32.

Ōkuma, Kotomichi 大隈言道 (1857) *: „Hitorigochi ひとりごち“. In: Ōkuma Kotomichi 大隈言 道 (Hgg. Sasaki, Nobutsuna 佐佐木信綱 und Umeno, Mitsuo 梅野満雄; Tōkyō: Sasaki Nobutsuna 佐佐木信綱, 1918): 1-16.

Ōkuma, Kotomichi 大隈言道 (1857): „Hitorigochi ひとりごち“. In: Ōkuma Kotomichi zenshū 大 隈言道全集 (Hg. Masamune, Atsuo 正宗敦夫; Tōkyō: Nihon Koten Zenshū Kankōkai 日本古 典全集刊行会, 1925-1933; Nihon koten zenshū 日本古典全集: Dai 1 ki 第1期 12): 239-255.

Ōnishi, Hajime 大西祝 (1888): „Hihyō ron 批評論“. In: Kokumin no tomo 国民之友, 2 (21 (Apr. 1888): 25.

Ōnuma, Chinzan 大沼枕山 (1859): „Chinzan shishō 枕山詩鈔“. In: Shishū Nihon kanshi 詩集日 本漢詩: Dai 17 kan 第17巻 (Hgg. Fujikawa, Hideo 富士川英郎, Matsushita, Tadashi 松下忠 und Sano, Masami 佐野正巳; Shishū Nihon kanshi 詩集日本漢詩, 17; Tōkyō: Kyūko Shoin 波古書院, 1983): 415-563.

Ōnuma, Chinzan 大沼枕山 (1869): Kanren shōkō 観蓮小稿. Tōkyō: Shitayagin Sha 下谷吟社.

Ōtani, Masuo 大谷万寿男 (1876): „Shibai wo haisubeki ron 芝居ヨ廃スベキ論“. In: Tōkei Akebono Shinbun 東京曙新聞 (792), 29. 05.1876: 3-4.

Ōtsuki, Bankei 大槻磐渓 (1855): Kinko shidan 近古史談 (4 Bde.). Tōkyō: Kobayashi Shinbē 小 林新兵衛, 1882.

Reishō koji 冷笑居士 (1889): „Kochō no buyōjin 胡蝶の不用心“. In: Yomiuri shinbun 読売新聞, 17.01.1889: 3 .

Ryūkantei shujin 龍閑亭主人 (1890): „Meiji bunshō no gettan 明治文章の月旦“. In: Nihon no bunka 日本之文華 (1 Jan. 1890): 4-67.

Ryūkatei, Tanekazu 柳下亭種員 (1850) *: Jiraiya gōketsu monogatari 児雷也豪傑譚(12 Bde.). Edo 江戸: Kansendō 甘泉堂.

Ryūkatei, Tanekazu 柳下亭種員, Utagawa, Kunisada 歌川 国貞 und Ryūtei, Tanehiko 柳亭種彦 (1849): Shiranui monogatari 白縫譚 (124 Bde.). Edo 江戸: Hirookaya 広岡屋, 1849-1885.

Ryūtei, Senka 笠亭仙果 (1850) *: Kyokutei ō ian Onna Suikoden 曲亭翁遺案女水滸伝 (20 Bde.). Tōto 東都: Shōjudō 松寿堂.

Ryūtei, Tanehiko Nisei 柳亭種彦二世 und Utagawa, Kunisada 歌川 国貞 (1863) *: Shiranui monogatari 白縫譚 (54 Bde.). Edo 江戸: Hirookaya 広岡屋.

Ryūtei, Tanehiko Nisei 柳亭種彦二世 und Utagawa, Kunisada 歌川 国貞 (1863): Shiranui monogatari 白縫譚 54. Edo 江戸: Hirookaya 広岡屋.

Ryūtei, Tanehiko 柳亭種彦 (1864) *: Muromachi Genji kochō no maki 室町源氏胡蝶巻 (13 Bde.). Edo 江戸: Kōeidō 紅英堂.

Saganoya, Omuro 嵯峨の屋御室 (1889): „Hōdaisai shujin ni kotau 方内斎主人に答ふ“. In: Futabatei Shimei - Saganoya Omuro shū二葉亭四迷・撯峨の屋おむろ集 (Hg. Nakamura, Mitsuo 中村光夫; Meiji bungaku zenshū 明治文学全集 17; Tōkyō: Chikuma Shobō 筑摩書 房, 1971): 332-335. 
Saganoya, Omuro 嵯峨の屋御室 (1889): „Shōsetsu ka no sekinin 小説家の責任“. In: Kindai hyōron shū 1 近代評論集I (Hg. Kawazoe, Kunimoto 川副国基; Nihon kindai bungaku taikei 日本近代文学大系, 57; Tōkyō: Kadokawa Shoten 角川書店, 1972): 102-105.

Saganoya, Omuro 嵯峨の屋御室 (1889): „Yoda sensei no “Ruten” no hihyō wo yomu 依田先生 の「流転」の批評を読む“. In: Kokumin no tomo 国民之友, 5 (67 (Nov. 1889): 27.

Saitō, Ryokuu 斉藤緑雨 (1889): „Shōsetsu hassō 小説八宗“. In: Amagaeru あま蛙 (9): 48-58.

Saitō, Ryokuu 斉藤緑雨 (1890): „Masanao Shōdayū cho Hatsu manabi shōsetsu no kokoroe 正 直正太夫著初学小説心得“. In: Saitō Rokuyu shū 齋藤緑雨集 (Hg. Inagaki, Tatsurō 稲垣達 郎; Meiji bungaku zenshū 明治文学全集, 28; Tōkyō: Chikuma Shobō 筑摩書房, 1966): 212-220.

Saitō, Ryokuu 斉藤緑雨 (1890): „Shōsetsu hyōchū mondō 小説評註問答“. In: Saitō Rokuyu shū 齋藤緑雨集 (Hg. Inagaki, Tatsurō 稲垣達郎; Meiji bungaku zenshū 明治文学全集, 28; Tōkyō: Chikuma Shobō 筑摩書房, 1966): 220-223.

Sakazaki, Shiran 坂崎紫欄 (1883): „Waga kuni ni jiyū no jushi wo hashoku suru ichi-shudan wa haishi gikyoku tō no rui wo kairyō suru ni ari 我国二自由ノ種子ヨ播殖スル一手段八稗史戯 曲等ノ類ヨ改良スルニ在リ “. In: Nihon Rikken Seitō Shinbun 日本立憲政党新聞: 15-19.

Sakazaki, Shiran 坂崎紫欄 (1885): „Seiji shōsetsu no kōryoku 政治小説の効力“. In: Meiji ki 1 明治期 I (Hgg. Yoshida, Seiichi 吉田精一 und Asai, Kiyoshi 浅井清; Kindai bungaku hyōron taikei 近代文学評論大系, 1; Tōkyō: Kadokawa Shoten 角川書店, 1971):

Sakazaki, Shiran 坂崎紫欄 (1889): „Bungaku gokusui 文学極衰“. In: Meiji ki 1 明治期 I (Hgg. Yoshida, Seiichi 吉田精一 und Asai, Kiyoshi 浅井清; Kindai bungaku hyōron taikei 近代文 学評論大系, 1; Tōkyō: Kadokawa Shoten 角川書店, 1971): 89.

Sakurai, Baishitsu 桜井梅室 (1868): Konjin haikai sendai hokku shū 今人俳諧千題発句集 (4 Bde.). Ōsaka 大阪: Meigyokudō 明玉堂.

Seki, Shigehiro 関重弘 und Fujita, Hisashi 藤田亀 (1861) *: Kinsei meika shishō 近世名家詩鈔 (3 Bde.). Heian 平安: Hishiya Yūshichirō 菱屋友七郎; Yōmandō 擁万堂.

Senge, Takazumi 千家尊澄 (1869): Kashin kō 歌神考. Tōkyō: Murakami Kanbē 村上勘兵衛.

Shigeno, An'eki 重野安繹 (1893): „Buntai 文体“. In: Tōkyō gakushi kaiin zasshi 東京学士会院 雑誌, 15 (10): 478-504.

Shionoya, Tōin 鹽谷宕陰 (1859) *: Kakkaron 隔䩬論. Edo 江戸: Suharaya Ihachi 須原屋伊八.

Shionoya, Tōin 鹽谷宕陰 (1870) *: „Rikugei ron 六芸論“. In: Tōin sonkō 宕陰存稿. Hg. Takeda, Den'emon 武田傳右衛門.

Shishō sei 刺笑生 (1889): „Shochū no hadaka kochō 書中の裸胡蝶“. In: Yomiuri shinbun 読売 新聞, 11.01.1889: 3.

Shōtei, Kinsui 松亭金水 (1855)*: Ōkawa jinsei roku 大川仁政録 (4 Bde.). Tōkyō: Onkodō 温故 堂, 1884.

Shōtei, Kinsui 松亭金水 (1856) *: Uguisuzuka chiyo no hatsu koe 鶯塚千代迺初声 (4 Bde.). Edo 江戸: Bun'ei dō 文永堂, 1856-1869.

Shōtei, Kinsui 松亭金水 (1862-1865)*: Temari uta sannin musume 求唄三人娘 (5 Bde.). Edo 江戸: Bun'ei dō 文永堂.

Shōtei, Kinsui 松亭金水 (1862-1865): „Temari uta sannin musume 毛逑唄三人娘“. In: Ninjōbon kankōkai [sōsho] 人情本刊行會[叢書], 12-13. Hg. Ninjōbon Kankōkai 人情本刊行 會; Tōkyō: Ninjōbon Kankōkai 人情本刊行會, 1915-1916.

Shōtei, Kinsui 松亭金水 und Hashimoto, Sadahide 橋本貞秀 (1852-1855) *: Chūyū Asakura nikki 忠勇阿佐倉日記 (15 Bde.). Tōkyō fu 東京府: Ōkawa Jōkichi 大川錠吉, 1883.

Shōtei, Kinsui 松亭金水, Jōno, Saigiku 条野採菊 und Utagawa, Yoshitora 歌川芳虎 (18561869): „Uguisuzuka chiyo no hatsu koe 鶯塚千代迺初声“. In: Uguisuzuka chiyo no hatsu 
koe 鶯塚千代迺初声 - Shunshoku tamadasuki 春色玉だすき (Hgg. Shōtei, Kinsui 松亭金 水, Murakami, Seijin 村上静人 und Jōno, Saigiku 条野採菊, Tōkyō: Ninjōbon Kankōkai 人 情本刊行會, 1916): 1-249.

Smiles, Samuel und Nakamura, Masanao 中村正直 (1870) *: Saigoku risshi hen 西国立志編: Genmei - Jijoron 原名・自助論. Tōkyō: Kihira Aiji 木平愛二, 1876.

Smiles, Samuel und Nakamura, Masanao 中村正直 (1870): Saigoku risshi hen 西国立志編: Genmei - Jijoron 原名・自助論. Tōkyō: Kihira Aiji 木平愛二, 1876.

Soshitsu, Kyūan 蘇室久安 (1865) *: Shōfū mukaku ben 蕉風無格弁 (3 Bde.). Edo 江戸: Suwaraya Mohē 須原屋茂兵衛.

Sudō, Nansui 須藤南翠 (1886): Usō manpitsu- Ryokusa dan 雨窗漫筆・緑篙談. Tōkyō: Shinshindō 駸々堂.

Sudō, Nansui 須藤南翠 (1888) *: Shosei shashin - Ryokusa dan 処世写真・緑㝨談: The Local Government. Tōkyō: Shōbundō 正文堂.

Sudō, Nansui 須藤南翠 (1888): Shosei shashin - Ryokusa dan 処世写真・緑㝨談: The Local Government. Tōkyō: Shōbundō 正文堂.

Suehiro, Tetchō 未広鉄腸 (1879) *: „Bungaku ron 文学論: Dai 1 第一“. In: Chōya shinbun 朝野 新聞, 17. 04.1879:2.

Suehiro, Tetchō 末広鉄腸 (1879) *: „Bungaku ron 文学論: Dai 2 第二“. In: Chōya shinbun 朝野 新聞, 19. 04.1879:2.

Suehiro, Tetchō 末広鉄腸 (1879) *: „Bungaku ron 文学論: Dai 3 第三“. In: Chōya shinbun 朝野 新聞, 27. 04.1879:2.

Suehiro, Tetchō 末広鉄腸 (1879) *: „Bungaku ron 文学論: Dai 4 第四“. In: Chōya shinbun 朝野 新聞, 30. 04.1879:2.

Suehiro, Tetchō 末広鉄腸 (1885): „Setchūbai 雪中梅“. In: Meiji seiji shōsetsu shū 明治政治小 説集: 2 (Hg. Yanagida, Izumi 柳田泉; Meiji bungaku zenshū 明治文学全集, 6; Tōkyō: Chikuma Shobō 筑摩書房, 1967): 11-162.

Tachibana, Akemi 橘曙覧 (1867) *: „Irori banashi 囲炉裡譚“. In: Tachibana Akemi zenshū 橘曙 覧全集. Hg. Ite, Imashige 井手今滋: 300-373.

Tachibana, Akemi 橘曙覧 (1867): „Irori banashi 囲炉裡譚“. In: Tachibana Akemi zenshū 橘曙 覧全集 (Hg. Ite, Imashige 井手今滋; Tōkyō: Iwanami Shoten 岩波書店, 1927): 300-373.

Taguchi, Ukichi 田口卯吉 (1879): „Shōka no setsu 唱歌の説“. In: Bungaku geijutsu hen 文学芸 術篇 (Hg. Kimura, Ki 木村毅; Meiji bunka zenshū 明治文化全集, 12; Tōkyō: Nihon Hyōron Sha 日本評論社, 1928): 524-527.

Taguchi, Ukichi 田口卯吉 (1886): Nippon no ishō oyobi jōkō 日本の意匠及情交: Ichimei Shakai kairyō ron一名社会改良論. Tōkyō: Keizai Zasshi Sha 経済雑誌社.

Takada, Sanae 高田早苗 (1886): „Tōsei shosei katagi no hihyō 当世書生気質の批評“. In: Kindai hyōron shū 1 近代評論集I (Hg. Kawazoe, Kunimoto 川副国基; Nihon kindai bungaku taikei 日本近代文学大系, 57; Tōkyō: Kadokawa Shoten 角川書店, 1972): 50-65.

Takada, Sanae 高田早苗 (1889): Biji gaku 美辞学: Zenpen 前編 - kōhen 後編 (2 Bde.). Tōkyō: Kinkōdō Shoseki 金港堂書籍, 1889.

Takahashi, Gorō 高橋五郎 (1892) *: „Chōshū sōsho 長周叢書: Kyojitsu kenmon ki 虚実見聞記: Hihyō 批評“. In: Kokumin no tomo 国民之友 (144 (Feb. 1892): 36.

Takizawa, Bakin 滝沢馬琴 (1814-1842) *: Nansō Satomi Hakkenden 南総里見八犬伝. Edo 江 戸: Sanseidō 山青堂; Chōjiya Heibē 丁子屋平兵衛; Bunkeidō 文渓堂; Yūsendō 涌泉堂.

Takizawa, Bakin 滝沢馬琴 (1814-1842): Nansō Satomi Hakkenden 南総里見八犬伝 (106 Bde.). Edo 江戸: Sanseidō 山青堂; Chōjiya Heibē 丁子屋平兵衛; Bunkeidō 文渓堂; Yūsendō 涌泉堂. 
Takizawa, Bakin 滝沢馬琴 und Shōtei, Kinsui 松亭金水 (1855) *: Asaina shima meguri no ki 朝 夷巡島記 (8 Bde.). Ōsaka 大坂: Kawachiya Daisuke 河内屋太助.

Takizawa, Bakin 滝沢馬琴 und Shōtei, Kinsui 松亭金水 (1855): Asaina shima meguri no ki 朝夷 巡島記 (8 Bde.). Ōsaka 大坂: Kawachiya Daisuke 河内屋太助.

Tamenaga, Shunsui Nisei 為永春水二世 (1853) *: Tenjiku tokubei Senkei kiroku 天竺得瓶仙桂 奇縁. Ōsaka 大阪: Gunpōdō 群鳳堂.

Taniguchi, Ken 谷口謙 (1869): Keiō shinsen shi shō 慶応新選詩鈔 (3 Bde.). Tōkyō: Kawachiya Usuke 河内屋卯助.

Tokutomi, Sohō 徳富蘇峰 (1887): „Kinrai ryūkō no seiji shōsetsu wo hyō su 近来流行の政治小 説を評す“. In: Kokumin no tomo 国民之友 (6 (Juli 1887): 7-15.

Tokutomi, Sohō 徳富蘇峰 (1888): „Insupirēshon インスピレーション“. In: Kokumin no tomo 国民之友, 2 (22 (Mai 1888): 9.

Tokutomi, Sohō 徳富蘇峰 (1889) *: „Genron no fujiyū to bungaku no hattatsu 言論の不自由と 文学の発達“. In: Kokumin no Tomo 国民之友, 4 (48 (April 1889): 1.

Tokutomi, Sohō 徳富蘇峰 (1890): „Hōchi ibun »Ukishiro monogatari« jo 報知異聞『浮城物 語』序“. In: Meiji ki 1 明治期 I (Hgg. Yoshida, Seiichi 吉田精一 und Asai, Kiyoshi 浅井清; Kindai bungaku hyōron taikei 近代文学評論大系, 1; Tōkyō: Kadokawa Shoten 角川書店, 1971): 102.

Tomono, Kashū 友野霞舟 (1847) *: „Kinten sanbō shiwa 錦天山房詩話: 2 satsu二冊“. In: Nihon shiwa sōsho 日本詩話叢書 8 (Hgg. Ikeda, Roshū 池田蘆洲 und Kokubu, Takatane 国分高胤; Tōkyō: Ōtori Shuppan 鳳出版, 1972): 303-525.

Toyama, Masakazu 外山正一 (1886) *: ,Engeki kairyō ron shikō 演劇改良論私考“. In: Kyōkasho 教科書 - Keimō bunshū 啓蒙文集 (Hgg. Saitō, Toshihiko 斉藤利彦, Kurata, Yoshihiro 倉田喜弘 und Tanikawa, Keiichi 谷川恵一; Shin Nihon koten bungaku taikei 新 日本古典文学大系: Meiji hen 明治編, 11; Tōkyō: Iwanami Shoten 岩波書店, 2006): 341-375.

Toyama, Masakazu 外山正一 (1890): Nihon kaiga no mirai 日本絵画ノ未来. Tōkyō: [Selbstverlag], 1890.

Toyama, Masakazu 外山正一, Yatabe, Ryōkichi 矢田部良吉 und Inoue, Tetsujirō 井上哲次郎 (1882): Shintai shishō 新体詩抄: Shohen 初編. Tōkyō: Maruya Zenshichi 丸屋善七.

Tsubouchi, Shōyō 坪内逍遥 (1885-1886) *: Shōsetsu shinzui 小説神髄 (9 Bde.). (Meicho fukkoku zenshū 名著復刻全集, 41-49). Tōkyō: Horupu ほるぷ, 1982.

Tsubouchi, Shōyō 坪内逍遥 (1886) *: „Bi to wa nan zo ya 美とは何ぞや“. In: Bijutsu 美術 (Hgg. Aoki, Shigeru 青木茂 und Sakai, Tadayasu 酒井忠康; Nihon kindai shisō taikei 日本 近代思想大系, 17; Tōkyō: Iwanami Shoten 岩波書店, 1989): 15-34.

Tsubouchi, Shōyō 坪内逍遥 (1886): „Bunshō shinron 文章新論“. In: Bungaku geijutsu hen 文 学芸術篇 (Hg. Kimura, Ki 木村毅; Meiji bunka zenshū 明治文化全集, 12; Tōkyō: Nihon Hyōron Sha 日本評論社, 1928): 547-553.

Tsubouchi, Shōyō 坪内逍遥 (1886): „Shōsetsu wo ronjite Shosei katagi no shu’i ni oyobu 小説 を論じて書生形気の主意に及ぶ“. In: Meiji ki 1 明治期 I (Hgg. Yoshida, Seiichi 吉田精一 und Asai, Kiyoshi 浅井清; Kindai bungaku hyōron taikei 近代文学評論大系, 1; Tōkyō: Kadokawa Shoten 角川書店, 1971): 27-28.

Tsubouchi, Shōyō 坪内逍遥 (1887) *: „Shōsetsu no shudan dai-1 小説の手段第一“. In: Yomiuri shinbun 読売新聞 (3683), 23. 04.1887:1.

Tsubouchi, Shōyō 坪内逍遥 (1887) *: „Shōsetsu no shudan dai-2 小説の手段第二“. In: Yomiuri shinbun 読売新聞, 26. 04.1887:1. 
Tsubouchi, Shōyō 坪内逍遥 (1887) *: „Shōsetsu no shudan dai-3 小説の手段第三: Shōsetsu no sanshu 小説の三種“. In: Yomiuri shinbun 読売新聞 (3687), 28. 04.1887:1.

Tsubouchi, Shōyō 坪内逍遥 (1887): ,Hihyō no hyōjun 批評の標準“. In: Chūō gakujutsu zasshi 中央学術雑誌 (58 (15. Sept. 1887): 1-8.

Tsubouchi, Shōyō 坪内逍遥 (1888): „Bijutsu ron 美術論“. In: Bungaku geijutsu hen 文学芸術 篇 (Hg. Kimura, Ki 木村毅; Meiji bunka zenshū 明治文化全集, 12; Tōkyō: Nihon Hyōron Sha 日本評論社, 1928): 553-560.

Tsubouchi, Shōyō 坪内逍遥 (1889)*: „Meiji nijū ni nen no chosaku ka 明治廿二年の著作家“. In: Yomiuri shinbun 読売新聞 (bessatsu), 15. 01.1889:1.

Tsubouchi, Shōyō 坪内逍遥 (1890): „Kihatsu shiban gōhyō (Shinsaku jūni ban no uchi-) 既発 四番合評 (新作十二番のうち)“. In: Meiji ki 1 明治期 I (Hgg. Yoshida, Seiichi 吉田精一 und Asai, Kiyoshi 浅井清; Kindai bungaku hyōron taikei 近代文学評論大系, 1; Tōkyō: Kadokawa Shoten 角川書店, 1971): 152-153.

Tsubouchi, Shōyō 坪内逍遥 (1890): „Meiji nijūni nen bungaku kai (omo ni shōsetsu kai) no fūchō 明治廿二年文学界 (重に小説界) の風潮“. In: Meiji ki 1 明治期 I (Hgg. Yoshida, Seiichi 吉田精一 und Asai, Kiyoshi 浅井清; Kindai bungaku hyōron taikei 近代文学評論大 系, 1; Tōkyō: Kadokawa Shoten 角川書店, 1971): 86-88.

Tsubouchi, Shōyō 坪内逍遥 (1890): „Shinbunshi no shōsetsu 新聞紙の小説“. In: Yomiuri shinbun 読売新聞 (bessatsu), 17. 01.1890:2.

Tsubouchi, Shōyō 坪内逍遥 (1890): „Waga kuni ni tsui ni Shēkusupia nakaran ya 我国竟に シェークスピア無からんや“. In: Yomiuri shinbun 読売新聞 (Bessatsu 別刷), 08. 01.1890:1.

Tsubouchi, Shōyō 坪内逍遥 (1891) *: „Azusa no miko 梓神子“. In: Yomiuri shinbun 読売新聞 (bessatsu), 15. 05.1891:2.

Tsubouchi, Shōyō 坪内逍遥 (1891) *: „Azusa no miko 梓神子: zenkō no tsuzuki 前項の続き“. In: Yomiuri shinbun 読売新聞 (bessatsu), 15. 05.1891:furoku.

Tsubouchi, Shōyō 坪内逍遥 (1891): „Dokuhō wo okosan to suru shui 読法を興さんとする趣意 “. In: Kokumin no tomo 国民之友, 8 (115): 11.

Tsubouchi, Shōyō 坪内逍遥 (1891): „Shēkusupia kyakuhon hyōchū シェークスピア脚本標柱“. In: Waseda bungaku 早稲田文学 (1 (Okt. 1891): 188-193.

Tsubouchi, Shōyō 坪内覓遥 (1892): „Botsu risō no gogi wo benzu 没理想の語義を弁ず“. In: Tsubouchi Shōyō shū 坪内逍遥集 (Hgg. Nakamura, Kan 中村完; Umezawa, Nobuo 梅澤宣 夫; Nihon kindai bungaku taikei 日本近代文学大系, 3; Tōkyō: Kadokawa Shoten 角川書 店, 1974): 190-193.

Tsubouchi, Shōyō 坪内逍遥 (1892): „Sono i wa chigaeri 其意は違へり“. In: Meiji ki 1 明治期 I (Hgg. Yoshida, Seiichi 吉田精一 und Asai, Kiyoshi 浅井清; Kindai bungaku hyōron taikei 近代文学評論大系, 1; Tōkyō: Kadokawa Shoten 角川書店, 1971): 219-220.

Tsubouchi, Shōyō 坪内逍遥 (1892): „Uyū sensei ni tou 烏有先生に答ふ: [3 Teile]“. In: Waseda bungaku 早稲田文学 (9-10 (Februar 1892): 195-219.

Tsubouchi, Shōyō 坪内逍遥 (1909): „Chikamatsu tai Shēkusupia tai Ibusen 近松対シェークス ピア対イブセン“. In: Shōyō senshū 逍遙選集: Fukkoku ban 復刻版, 10 (Hg. Shōyō Kyōkai 逍遥協会; Tōkyō: Daiichi Shobō 第一書房, 1977): 769-813.

Tsubouchi, Shōyō 坪内逍遥 und Shakespeare, William (1884): Shīzaru kidan Jiyū no tachi nagori no kireaji 該撒奇談自由太刀余波鋭鋒. Tōkyō: Tōyōkan Shuppansha 東洋館出版社.

Tsukinoya Sango 月のや三五 (1889): „Rakochō ni tsuite 裸胡蝶に付て“. In: Yomiuri shinbun 読売新聞, 17. 01.1889:3. 
Uchida, Roan 内田魯庵 (1888): „Yamada Bimyō taijin no shōsetsu 山田美妙大人の小説“. In: Jogaku zasshi 女学雑誌 (1888, Okt. 20, Nov. 3).

Uchida, Roan 内田魯庵 (1889): „Bakin no shōsetsu 馬琴の小説“. In: Jogaku zasshi 女学雑誌 (11 (Mai): 138.

Uchida, Roan 内田魯庵 (1889): „Bakin shōsetsu no kōka 馬琴小説の効果“. In: Uchida Roan shū 内田魯庵集 (Hg. Inagaki, Tatsurō 稲垣達郎; Meiji bungaku zenshū 明治文学全集, 24; Tōkyō: Chikuma Shobō 筑摩書房, 1978): 139.

Uchida, Roan 内田魯庵 (1889): „Bunkai manpo 文海漫歩: Bijutsu jō no shi seishitsu 美術上の 四性質 (Ichi一)“. In: Kokumin no tomo 国民之友, 4 (48 (Apr. 1889): 21.

Uchida, Roan 内田魯庵 (1889): „Bunkai manpo 文海漫歩: Bijutsu jō no shi seishitsu 美術上の 四性質 (Ni 二)“. In: Kokumin no tomo 国民之友, 5 (55 (Jul. 1889): 23-25.

Uchida, Roan 内田魯庵 (1889): „Bunkai manpo 文海漫歩: Bijutsu jō no shi seishitsu 美術上の 四性質 (Ni 二)“. In: Kokumin no tomo 国民之友, 5 (55 (Jul. 1889): 23-25.

Uchida, Roan 内田魯庵 (1889): „Bunkai manpo 文海漫歩: Shijin wa kokugo wo motte utawazaru bekarazu 詩人ハ国語ヨ以テ歌ハザルベカラズ (Sono ni 其ニ)“. In: Kokumin no tomo 国民之友, 4 (37 (Jan. 1889): 22-25.

Uchida, Roan 内田魯庵 (1889): ,Jogaku zasshi no shōsetsu ron 女学雑誌の小説論“. In: Uchida Roan shū 内田魯庵集 (Hg. Inagaki, Tatsurō 稲垣達郎; Meiji bungaku zenshū 明治文学全 集, 24; Tōkyō: Chikuma Shobō 筑摩書房, 1978): 142-144.

Uchida, Roan 内田魯庵 (1889): „Kōyō Sanjin no “Irozange” 紅葉山人の「色懺悔」: Sono ni 其 のニ“. In: Jogaku zasshi 女学雑誌 (159): 7-9.

Uchida, Roan 内田魯庵 (1889): „Nihon shōsetsu no santaika 日本小説の三大家“. In: Uchida Roan shū 内田魯庵集 (Hg. Inagaki, Tatsurō 稲垣達郎; Meiji bungaku zenshū 明治文学全 集, 24; Tōkyō: Chikuma Shobō 筑摩書房, 1978): 152.

Uchida, Roan 内田魯庵 (1889): „Shibun no kan’ō 詩文の感応“. In: Kokumin no tomo 国民之友 (55 (Juli 1889): 14-17.

Uchida, Roan 内田魯庵 (1890): „“Ukishiro monogatari” wo yomu「浮城物語」を読む“. In: Kokumin shinbun 国民新聞 (97 furoku), 08. 05.1890:2.

Uchida, Roan 内田魯庵 (1890): „“Ukishiro monogatari” wo yomu「浮城物語」を読む: Sono ni 其二“. In: Kokumin shinbun 国民新聞 (105 furoku), 16. 05.1890:1.

Uchida, Roan 内田魯庵 (1910): „VITA SEXUALIS“. In: Uchida Roan shū 内田魯庵集 (Hg. Inagaki, Tatsurō 稲垣達郎; Meiji bungaku zenshū 明治文学全集, 24; Tōkyō: Chikuma Shobō 筑摩 書房, 1978): 252-255.

Uchida, Roan 内田魯庵 und Yokoyama, Gennosuke 横山源之助 (1911): „Shōsetsu kyakuhon wo tsūjite mitaru gendai shakai 小説脚本を通じて観たる現代社会“. In: Taiyō 太陽, 17 (3 (Feb. 1911): 107-113.

Umebori, Kokuga Nisei 梅暮里谷峨二世, Utagawa, Sadahide 歌川貞秀 und Utagawa, Yoshitorijo 歌川芳鳥女 (1852-1858) *: Shunshoku renri no ume 春色連理の梅. (3 Bde.). Ort und Verlag unbekannt, 1852-1858.

Umebori, Kokuga Nisei 梅暮里谷峨二世, Utagawa, Sadahide 歌川貞秀 und Utagawa, Yoshitorijo 歌川芳鳥女 (1852-1858): Shunshoku renri no ume 春色連理の梅. (3 Bde.). Ort und Verlag unbekannt, 1852-1858.

Yamada, Bimyō 山田美妙 (1889): „Kochō oyobi Kochō no zu ni tsuki Gakkai Sensei to Sazanami Sanjin to no hyō 蝴蝶及び蝴蝶の図に就き学海先生と漣山人との評“. In: Kokumin no tomo 国民之友, 4 (40): 31. 
Yamada, Bimyō 山田美妙 (1890): „Bungaku gokusui? 文学極衰?“. In: Meiji ki 1 明治期 /(Hgg. Yoshida, Seiichi 吉田精一 und Asai, Kiyoshi 浅井清; Kindai bungaku hyōron taikei 近代文 学評論大系, 1; Tōkyō: Kadokawa Shoten 角川書店, 1971): 93-94.

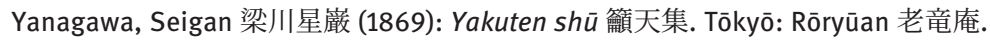

Yano, Fumio 矢野文雄 (1883): Yakusho doppō 訳書読法. Tōkyō: Hōchisha 報知社.

Yano, Ryūkei 矢野龍渓 (1890) *: Hōchi ibun Ukishiro monogatari 報知異聞浮城物語. Tōkyō: Hōchisha 報知社.

Yano, Ryūkei 矢野龍渓 (1890): „Ukishiro monogatari ritsuan no shimatsu 浮城物語立案の始 末: [1]“. In: Kokumin shinbun 国民新聞 (148), 28. 06.1890:1.

Yano, Ryūkei 矢野龍渓 (1890): „Ukishiro monogatari ritsuan no shimatsu 浮城物語立案の始 末: [2] Tsuzuki 続“. In: Kokumin shinbun 国民新聞 (150), 30. 06.1890:1.

Yano, Ryūkei 矢野龍渓 (1890): „Ukishiro monogatari ritsuan no shimatsu 浮城物語立案の始 末: [3] Tsuzuki 続“. In: Kokumin shinbun 国民新聞 (151), 01. 07.1890:1.

Yano, Ryūkei 矢野龍渓 (1890): „Ukishiro monogatari ritsuan no shimatsu 浮城物語立案の始 末: [4] Tsuzuki 続“. In: Kokumin shinbun 国民新聞 (151), 01. 07.1890:1.

Yano, Ryūkei 矢野龍渓 (1890): „Ukishiro monogatari ritsuan no shimatsu 浮城物語立案の始 末: [4] Tsuzuki 続“. In: Kokumin shinbun 国民新聞 (152), 02. 07.1890:1.

Yasuoka, Reinan 保岡嶺南 und Shionoya, Tōin 鹽谷宕陰 (1883): Sonshi tokuhon 孫子読本 (3 Bde.). Tōkyō: Yasuoka Shōtarō 保岡正太郎.

Yoda, Gakkai 依田学海 (1889): „Kokumin no tomo ni shōsetsu hyō 国民之友二小説評: [1]“. In: Kokumin no tomo 国民之友, 4 (39 (Jan. 1889): 23.

Yoda, Gakkai 依田学海 (1889): „Kokumin no tomo ni shōsetsu hyō 国民之友二小説評: [2] Haru no ya kun shōsetsu Saikun 春の舎君小説細君“. In: Kokumin no tomo 国民之友, 4 (41 (Jan. 1889): 23.

\subsection{Primärquellen}

»Primärquellen« meint hier die Gruppe jener Texte, aus welchen die Texte des »Korpus« direkt oder indirekt geschöpft haben.

[Anonymus] (9. Jhdt.): Fupu 賦譜. Bearb. Nakazawa, Mareo 中沢希男: „Fufu kōsen 賦譜校箋“. In: Gunma daigaku kyōiku gakubu kiyō - Jinbun-shakai gaku hen 群馬大学教育学部紀 要・人文社会科学編 (17 (1967): 217-233.

[Anonymus] (1924-1934): „Bussetsu Hokkugyō so 仏説法句経疏“. In: Taishō Shinshū Daizōkyō 大正新脩大藏經 (Hgg. Takakusu, Junjirō 高楠順次郎, Ono, Genmyō 小野玄妙 und Izumi, Tokujō 和泉得成. Tōkyō: Taizō Shuppan 大蔵出版): 1435-1445.

[Anonymus] (1924-1934): „Bussetsu Hokkugyō 仏説法句経“. In: Taishō Shinshū Daizōkyō 大 正新脩大藏經 (Hgg. Takakusu, Junjirō 高楠順次郎, Ono, Genmyō 小野玄妙 und Izumi, Tokujō 和泉得成. Tōkyō: Taizō Shuppan 大蔵出版): 1432-1435.

Arashi, Akinari 阿知子顕成 (1670): „Zoku sakaigusa 続境海草“. In: Danrin haikai shū 談林俳諧集 (Hgg. lida, Masakazu 飯田正一, Esaka, Hironao 榎坂浩尚 und Inui, Hiroyuki 乾裕幸; Koten haibungaku taikei 古典俳文学大系, 3-4; Tōkyō: Shūeisha 集英社, 1971-1972): 133-195.

Aristoteles und Schmitt, Arbogast (335 v.Chr.): Poetik. (Aristoteles Werke in deutscher Übersetzung, 5). Berlin: Akademie Verlag, 2008. 
Asaka, Gonsai 安積艮斎, Kikuta, Toshirō 菊田紀郎 und Andō, Tomoshige 安藤智重 (1853): Gonsai shiryaku 艮斎詩略. Tōkyō: Meitoku Shuppansha 明徳出版社, 2010.

Cai, Zhengsun 蔡正孫 (1289): „Shirin kōki 詩林広記“ [Shilin guangji]. In: Wakokubon kanseki zuihitsu shū 和刻本漢籍随筆集: Dai 18 shū 第18集 (Hg. Nagasawa, Kikuya 長澤規矩也; Tōkyō: Kyūko Shoin 汲古書院, 1977): 1-203.

Chambers, William und Chambers, Robert (1852): Political Economy, for Use in Schools, and for Private Instruction. (Chambers Educational Course). Edinburgh: William and Robert Chambers.

Chambers, William und Chambers, Robert (Hgg.) (1835): Chamber's information for the people (2 Bde.). London: Chambers, 1874-1875.

Chunqiu Zuozhuan 春秋左伝 (5. Jhdt. a.Chr.). The I Ching (The Sacred Books of China: The Texts of Confucianism, 16). Hg. Legge, James. Oxford: Clarendon Press.

Cui, Rong 崔融 ([706?]): Xinding shige 新定詩格.

Fenollosa, Ernest und Ōmori, Ichū 大森惟中 (1882): Bijutsu shinsetsu 美術真説. Matsuo Yoshisuke 松尾犠助.

Fujiwara, Sadaie 藤原定家 (1219): „Maigetsu shō 毎月抄“. In: Karon shū 歌論集 - Nōgakuron shū 能楽論集 (Hgg. Hisamatsu, Sen’ichi 久松潜一 und Nishio, Minoru 西尾実; Nihon koten bungaku taikei 日本古典文学大系, 65; Tōkyō: Iwanami Shoten 岩波書店, 1969): 125-139.

Fujiwara, Shunzei 藤原俊成 (1197): „Korai fūtei shō古来風躰抄: Shosenbon 初撰本“. In: Nihon kagaku taikei 日本歌学大系: Dai 2 kan 第2巻 (Hg. Sasaki, Nobutsuna 佐佐木信綱; Nihon kagaku taikei 日本歌学大系, 2; Tōkyō: Kazama Shobō 風間書房, 1958): 303-414.

Fujiwara, Shunzei 藤原俊成 (1197): „Korai fūtei shō古来風身抄“. In: Karon kagaku shūsei dai 7 kan 歌論歌学集成第7巻 (Hgg. Watanabe, Yasuaki 渡部泰明, Kobayashi, Kazuhiko 小林 一彦 und Yamamoto, Hajime 山本一; Tōkyō: Miyai Shoten 三弥井書店, 2006): 25-174.

Fukumoto, Ichirō 復本一郎 (1718): Onitsura no “Hitorigoto” 鬼貫の『独ごと』. (Kōdan sha gakujutsu bunko 講談社学術文庫, 556). Tōkyō: Kōdansha 講談社, 1981.

Fukuzawa, Yukichi 福沢諭吉 (1866-1868): „Seiyō jijō 西洋事情“. In: Fukuzawa Yukichi zenshū 福沢諭吉全集: Dai 1 kan 第一巻. (Tōkyō: Iwanami Shoten 岩波書店, 1958): 275-608.

Fukuzawa, Yukichi 福沢諭吉 (1880): Gakumon no susume 学問ノススメ. Tōkyō: Fukuzawa Yukichi 福沢諭吉, 1880.

Fukuzawa, Yukichi 福沢諭吉 (1899): „Fukuō jiden 福翁自伝“. In: Fukuzawa Yukichi shū 福澤諭 吉集 (Hg. Matsuzawa, Hiroaki 松沢弘陽; Shin Nihon koten bungaku taikei 新日本古典文学 大系: Meiji hen 明治編, 10; Tōkyō: Iwanami Shoten 岩波書店, 2011): 1-382.

Gion, Nankai祇園南海 und Ikeda, Roshū 池田蘆洲 (1736): „Shigaku hōgen 詩学逢原“. In: Nihon shiwa sōsho 日本詩話叢書, 2 (Hgg. Ikeda, Roshū 池田蘆洲 und Kokubu, Takatane 国分高胤; 2. Aufl. Tōkyō: Ōtori Shuppan 鳳出版, 1972): 1-41.

Goethe, Johann Wolfgang von (1819): „Noten und Abhandlungen zu besserem Verständnis des West-östlichen Divans“ In: Werke 3 (Hg. Trunz, Erich; Hamburger Ausgabe in 14 Bänden; München: Deutscher Taschenbuch Verlag: 126-267.

Gottschall, Rudolf von (1858): Poetik: Die Dichtkunst und ihre Technik: Vom Standpunkte der Neuzeit. 4. Aufl. Breslau: Eduard Trewendt, 1877.

Hartmann, Eduard von (1869): Philosophie des Unbewussten: speculative Resultate nach inductiv-naturwissenschaftlicher Methode. 4. Aufl. Berlin: C. Dunckers Verlag (C. Heymons), 1872.

Hattori, Dohō 服部土芳 (1702): „Sanzōshi 三冊子“. In: Renga ron shū 連歌論集 - Hairon shū 俳論集 (Hgg. Kidō, Saizō 木藤才蔵 und Imoto, Nōichi 井本農一; Nihon koten bungaku taikei 日本古典文学大系, 66; Tōkyō: Iwanami Shoten 岩波書店, 1961): 379-452. 
Hegel, Georg Wilhelm Friedrich (1812-1816): Wissenschaft der Logik I: Erster Teil: Die objektive Logik: Erstes Buch. (Suhrkamp-Taschenbuch Wissenschaft, 605). Frankfurt am Main: Suhrkamp, 1986.

Hegel, Georg Wilhelm Friedrich (1812-1816): Wissenschaft der Logik II: Zweiter Teil: Die subjektive Logik. (Suhrkamp-Taschenbuch Wissenschaft, 606). Frankfurt am Main: Suhrkamp, 1986.

Hegel, Georg Wilhelm Friedrich (1830): Wissenschaft der Logik: Erster Teil: Die objektive Logik: Zweites Buch; Zweiter Teil: Die subjektive Logik. Auf der Grundlage der Werke von 18321845 neu edierte Ausgabe. (Georg Wilhelm Friedrich Hegel Werke, 6). Frankfurt (Main): Suhrkamp, 1986-1990.

Hegel, Georg Wilhelm Friedrich (1832-1845): Enzyklopädie der philosophischen Wissenschaften im Grundrisse 1830: Erster Teil: Die Wissenschaft der Logik mit den mündlichen Zusätzen (Hgg., Moldenhauer, Eva und Michel, Karl Markus: Auf der Grundlage der Werke von 1832-1845 neu edierte Ausgabe; Georg Wilhelm Friedrich Hegel Werke, 8-10). Frankfurt (Main): Suhrkamp, 1986-1990.

Hegel, Georg Wilhelm Friedrich (1832-1845): Vorlesungen über die Ästhetik. In: Werke: Auf der Grundlage der_Werke_von 1832-1845 neu edierte Ausgabe, Bde.13-15. Hgg. Moldenhauer, Eva und Michel, Karl M. Michel. Frankfurt am Main: Suhrkamp (Theorie Werkausgabe), 1969-1979.

Hegel, Georg Wilhelm Friedrich (1840): Vorlesungen über die Philosopie der Religion II. (Georg Wilhelm Friedrich Hegel Werke, 17). Frankfurt a. M.: Suhrkamp, 1986.

Hōjō, Dansui 北条団水 (1691): „Danbukuro 団袋“. In: Hōjō Dansui shū 北条団水集: Haikai hen 俳諧篇 (Hgg. Noma, Kōshin 野間光辰 und Yoshida, Kōichi 吉田幸一; Kinsei bungei shiryō 近世文芸資料, 18; Tōkyō: Koten Bunko 古典文庫, 1982-1983): 127-158.

Hosokawa, Yūsai 細川幽斎 und Karasumaru, Mitsuhiro 烏丸光広 (1602): „Jitei ki 耳底記“. In: Nihon kagaku taikei Dai 6 kan 日本歌学大系第6巻 (Hg. Sasaki, Nobutsuna 佐佐木信綱; Nihon kagaku taikei 日本歌学大系, 6; Tōkyō: Kazama Shobō 風間書房, 1956): 141-208.

Inoue, Tetsujirō 井上哲次郎 (1884): „Nakamura Keiu ō ni yosete sho su 寄中村敬宇翁書“. In: Sonken shishō 巽軒詩鈔: 11b-16a.

Itō, Tōgai 伊藤東涯 (1802): Sōko jiketsu 操触字訣: Hoi tsuki 附補遺. Tōkyō: Suwaraya Mohē 須 原屋茂兵衛, 1907.

Kagami, Shikō 各務支考 (1719): „Haikai jūron 俳諧十論“. In: Shōmon haiwa bunshū 蕉門俳話 文集 (Hg. Kanda, Toyoho 神田豊穂; Nihon haisho taikei 日本俳書大系, 4); Tōkyō: Shunjūsha 春秋社, 1926): 49-95.

Kagami, Shikō 各務支考 (1725): ,Jūron iben shō 十論為辯抄“. In: Shōmon haikai shū 蕉門俳諧 集 (Hgg. Abe, Kimio 阿部喜三男, Abe, Masami 阿部正美 und Ōiso, Yoshio 大礒義雄; Koten haibungaku taikei 古典俳文学大系, 6-7; Tōkyō: Shūeisha 集英社, 1971-1972): 549-625.

Kagami, Shikō 各務支考 (1736): „Nijūgo kajō二十五箇条“. In: Shōmon hairon haibun shū 蕉 門俳論俳文集 (Hgg. Ōiso, Yoshio 大礒義雄 und Ōuchi, Hatsuo 大内初夫; Koten haibungaku taikei 古典俳文学大系, 10; Tōkyō: Shūeisha 集英社, 1970): 67-76.

Ki no Tomonori 紀友則, Ki no Tsurayuki 紀貫之, Ōshikouchi no Mitsune 凡河内躬恒, Mibu no Tadamine 壬生忠岑 und Saiki, Umetomo 佐伯梅友 (914): Kokin wakashū 古今和歌集. (Nihon koten bungaku taikei 日本古典文学大系, 8). Tōkyō: Iwanami Shoten 岩波書店, 1958.

Ki no Tsurayuki 紀貫之 (930-934): „Shinsen waka jo 新撰和歌序“. In: Nihon kagaku taikei dai 1 kan 日本歌学大系第1巻 (Hg. Sasaki, Nobutsuna 佐佐木信綱; Nihon kagaku taikei 日本歌 学大系, 1; Tōkyō: Kazama Shobō 風間書房, 1956): 44. 
Kihara, Sōen 木原宗円 (1680): „Orandamaru niban sen 阿蘭陀丸二番船“. In: Danrin haikai shū 談林俳諧集 (Hgg. lida, Masakazu 飯田正一, Esaka, Hironao 榎坂浩尚 und Inui, Hiroyuki 乾裕幸; Koten haibungaku taikei 古典俳文学大系, 3-4; Tōkyō: Shūeisha 集英社, 1971-1972): 417-447.

Kitamura, Kigin 北村季吟 (1676): „Haikai yōi fūtei 俳諧用意風躰“. In: Kigin hairon shū 季吟俳 論集 (Koten bunko 古典文庫, 151; Tōkyō: Koten Bunko 古典文庫, 1960): 191-224.

Kōbō Daishi 弘法大師 (810-824): „Bunkyō hifu ron 文鏡秘府論“. In: Kōbō Daishi zenshū dai 3 shū 弘法大師第三輯 (Hg. Hase, Hōshū 長谷宝秀; Kōbō Daishi zenshū 弘法大師全集, Bde. 8-10; Tōkyō: Yoshikawa Kōbun Kan 吉川弘文館, 1910): 1-206.

Kūkai 空海 (810-824): „Bunkyō hifu ron 文鏡秘府論“. In: Shiwen pinglei 詩文評類 (Hg. Xuxiu Siku Quanshu Bianzuan Weiyuanhui 續修四庫全書編纂委員会; Xuxiu siku quanshu續修 四庫全書: Ji bu 集部, 1694; Shanghai 上海: Shanghai guji chuban she 上海古籍出版社, 1995-2002): 20-141.

Kūkai 空海 und Konishi, Jin’ichi 小西甚一 (810-824): Bunkyō hifu ron kō 文鏡秘府論考 (2 Bde.). Tōkyō: Dai Nihon Yūbenkai Kōdansha 大日本雄辯會講談社, 1953-1954.

Laozi 老子 (6. Jhdt.v.Chr.): In: Rōshi 老子 - Sōji 荘子 (Hgg. Ichikawa, Yasushi 市川安司; Endō, Tetsuo 遠藤哲夫; Shinshaku kanbun taikei 新釈漢文大系, 7; Tōkyō: Meiji Shoin 明治書院, 1985): 3-130.

Lessing, Gotthold Ephraim (1767-1769): „Hamburgische Dramaturgie“. In: Werke in drei Bänden: Nach den Ausgaben letzter Hand unter Hinzuziehung der Erstdrucke 2 (München: Winkler Verlag, 1969): 276-698.

Lessing, Gotthold Ephraim (1780): „Die Erziehung des Menschengeschlechts“. In: Werke in drei Bänden: Nach den Ausgaben letzter Hand unter Hinzuziehung der Erstdrucke, 3 (München: Winkler Verlag, 1969): 1110-1132.

Liu, Xie 劉劦思 (520): Wenxin diaolong 文心雕龍. In: Bunshin chōryū 文心雕龍. Hg. Toda, Kōgyō 戸田浩暁. (Shinshaku kanbun taikei 新釈漢文大系, 64-65). 6. Aufl. Tōkyō: Meiji Shoin 明 治書院, 1983.

Luo, Dajing 羅大経 (1248): „Helin yulu 鶴林玉露“. In: Wakokubon Kanseki zuihitsu shū Dai 8 $s h \bar{u}$ 和刻本漢籍随筆集第8集 (Hg. Nagasawa, Kikuya 長澤規矩也; Tōkyō: Kyūko Shoin 波 古書院, 1973): 1-199.

Matsuo, Bashō 松尾芭蕉 (1690-1691): „Oi no kobumi 笈の小文“. In: Bashō bunshū 芭蕉文集 (Hgg. Sugiura, Shōichirō杉浦正一郎, Miyamoto, Saburō 宮本三郎und Ogino, Kiyoshi 荻野 清; Nihon koten bungaku taikei 日本古典文学大系, 46; Tōkyō: Iwanami Shoten 岩波書店, 1970): 51-64.

Matsuo, Bashō 松尾芭蕉, Kogakuan, Bukkei 古学庵仏兮, Gensō Kochū 幻空湖中 und Toyoshima, Yusei 豊島由誓 (1827): Haikai ichiyō shū 俳諧一葉集 (5 Bde.). Edo 江戸: Ichiguan 一具菴.

Matsuzaki, Kōdō 松崎慊堂 und Yamada, Taku 山田琢 (1823): Kōdō nichireki 慊堂日暦 (6 Bde.). Tōkyō: Heibonsha 平凡社, 1970.

Mengzi 孟子 (3. Jhdt.v.Chr.): Mōshi 孟子. Hg. Uchino, Kumaichirō 内野熊一郎. Shinshaku kanbun taikei 新釈漢文大系, 4. 6. Aufl. Tōkyō: Meiji Shoin 明治書院, 1964.

Miki, Heiemon Sadanari 三木平衛門貞成 und Hozumi, Ikan穂積以貫 (1738): „Jōruri monku hyōchū Naniwa miyage 浄瑠璃文句評註難波土産: Hottan 発端“. In: Jōruri kenkyū bunken shūsei 浄瑠璃研究文献集成 (Hg. Nihon Engeki Bunken Kenkyūkai 日本演劇文献研究会; Tōkyō: Hokkō Shobō 北光書房, 1944): 68-74. 
Minagawa, Kien 皆川淇園 (1771): „Kien shiwa 淇園詩話“. In: Nihon shiwa sōsho 日本詩話叢 書, 5 (Hgg. Ikeda, Roshū 池田蘆洲 und Kokubu, Takatane 国分高胤; Tōkyō: Ōtori Shuppan 鳳出版, 1972): 177-226.

Morikawa, Kyoroku 森川許六 und Kimura, [Kakemuro] 木村架室 (Hgg.) (1714): Wakun Santai $s h i$ 和訓三体詩. Tōkyō: Kōeki Tosho 広益図書, 1899.

Mukai, Kyorai 向井去来 (1775): „Kyorai shō 去来抄“. In: Renga ron shū 連歌論集 - Hairon shū 俳論集 (Hgg. Kidō, Saizō 木藤才蔵 und Imoto, Nōichi 井本農一; Nihon koten bungaku taikei 日本古典文学大系, 66; Tōkyō: Iwanami Shoten 岩波書店, 1961): 303-377.

Mukai, Kyorai 向井去来 und Morikawa, Kyoroku 森川許六 (1785): „Haikai mondō Aone ga mine 俳諧問答青根が峰 “. In: Shōmon haiwa bunshū 蕉門俳話文集 (Hg. Kanda, Toyoho 神田豊 穂; Nihon haisho taikei 日本俳書大系, 4; Tōkyō: Shunjūsha 春秋社, 1926): 409-486.

Mukai, Kyorai 向井去来 und Takarai, Kikaku 宝井其角 (1775): „Shi Shin mondō 柿晋問答“. In: Shōmon haiwa bunshū 蕉門俳話文集 (Hg. Kanda, Toyoho 神田豊穂; Nihon haisho taikei 日本俳書大系, 4; Tōkyō: Shunjūsha 春秋社, 1926): 191-216.

Murasaki Shikibu 紫式部 (1010): Genji monogatari 源氏物語. Tōkyō: Iwanami Shoten 岩波書 店, 1969 (Nihon koten bungaku taikei 日本古典文学大系, 14-18).

Mutobe, Yoshika 六人部是香 (1861): Chōka tamagoto 長歌玉琴 [unbekannt]: [unbekannt]. Nakamura, Masanao 中村正直 (1883): „Inoue Sonken ni kotaete sho su 答井上巽軒書“. In: Keiu bunshū 敬宇文集, 1 (Tōkyō: Yoshikawa Kōbun Kan 吉川弘文館, 1903): 14b -18b. Natsume, Sōseki 夏目漱石 (1907): Bungaku ron 文学論. Tōkyō: Ōkura Shoten 大倉書店.

Ogyū, Sorai 荻生徂徠 (1717): „Benmei 弁名“. In: Ogyū Sorai 荻生徂徠 (Hg. Yoshikawa, Kōjirō 吉川幸次郎; Nihon shisō taikei 日本思想大系, 36; Tōkyō: Iwanami Shoten 岩波書店, 1974): 37-185; 209-255.

Okanishi, Ichū 岡西惟中 (1675): „Haikai mōgyū 俳諧蒙求“. In: Danrin haikai shū 談林俳諧集 (Hgg. lida, Masakazu 飯田正一, Esaka, Hironao 榎坂浩尚 und Inui, Hiroyuki 乾裕幸; Koten haibungaku taikei 古典俳文学大系, 3-4; Tōkyō: Shūeisha 集英社, 1971-1972): 82-111.

Okanishi, Ichū 岡西惟中 (1678): „Haikai wakumon 俳諧或問“. In: Hairon sakuhō shū 俳論作法 集 (Hgg. Sassa, Seisetsu 佐々醒雪 und Iwaya, Sazanami 巌谷小波; Haikai sōsho 俳諧叢 書, 4; Tōkyō: Hakubunkan 博文館, 1914): 1-29.

Saigyō 西行 (1250): Senjū shō 撰集抄. Tōkyō: Gendai shichō sha 現代思潮社, 1985-1987.

Santō, Kyōden 山東京伝 (1791): „Seirō hiru no sekai Nishiki no ura 青楼昼之世界錦之裏“. In: Kibyōshi Sharebon shū 黄表紙 酒落本集 (Hg. Mizuno, Minoru 水野稔; Nihon koten bungaku taikei 日本古典文学大系, 59; 8. Aufl. Tōkyō: Iwanami Shoten 岩波書店, 1969): 417-440.

Sawano, Chūan 沢野忠庵 und Mukai, Genshō 向井玄松 (1658): „Kenkon bensetsu 乾坤弁説“. In: Bunmei genryū sōsho 文明源流叢書 (3 Bde.) (Hg. Kokusho Kankōkai 国書刊行会; Tōkyō: Kokusho Kankōkai 国書刊行会, 1913-1914): 1-100.

Sessai 雪柴 und Kataoka, Eizō 片岡英三 (1678): „Urokogata うろこかた“ [鱗形]. In: Haisho sōkan 俳書叢刊: Dai 3 kan 第三巻 (Hgg. Kataoka, Eizō 片岡英三 und Tenri Daigaku Toshokan Nishikiya Bunko 天理大学図書館綿屋文庫; Kyōto 京都: Rinsen Shoten 臨川書 店, 1988): 335-379.

Shōtei, Kinsui 松亭金水, Utagawa, Kuniteru 歌川 国輝 und Nishimura, Shin 西村新 (18391841): Kanjō suetsumu hana 閑情末摘花. (Edo nanpa zenshū 江戸軟派全集). Tōkyō: Edo Nanpa Zenshū Kankōkai 江戸軟派全集刊行会, 1926.

Sidney, Philip (1595): An Apology for Poetry or the Defence of Poesy [sic!]. Hg. Shepherd, Geoffrey und Maslen, Robert W. (1965): 3. Aufl. Manchester: Manchester University Press, 2002. 
Smiles, Samuel (1859): Self-Help: With Illustrations of Character and Conduct. Boston: Ticknor \& Fields.

Sunzi 孫子 (4.Jhdt.v.Chr.): Sunzi bingfa zhi zonghe yanjiu 孫子兵法. Bearb. Li, Yuri 李浴日. 2. Aufl. Hongkong: Shiyong Zhishi Chubanshe 実用知識出版社, 1987.

Tachibana, Moribe 橘守部 (1875): „Tanka senkaku 短歌撰格“. In: Nihon kagaku taikei 日本歌 学大系: Bekkan 9 別巻 9 (Hg. Kyūsojin, Hitaku 久曾神昇; Tōkyō: Kazama Shobō 風間書房, 1992): 333-385.

Taira, Yasuyori 平康頼 (1179): „Hōbutsu shū 宝物集“. In: Hōbutsu shū 宝物集 - Kankyo no tomo 閑居友 - Hirasan kojin reitaku 比良山古人霊託 (Hgg. Koizumi, Hiroshi 小泉弘, Yamada, Shōzen 山田昭全, Kojima, Takayuki 小島孝之 und Kinoshita, Motoichi 木下資一; Shin Nihon koten bungaku taikei 新日本古典文学大系, 40; Tōkyō: Iwanami Shoten 岩波書 店, 1993): 1-353.

Takarai, Kikaku 宝井其角 und Matsuo, Bashō 松尾芭蕉 (1680): „Inaka no kuawase 田舎の句合 “. In: Bashō bunshū 芭蕉文集 (Hgg. Sugiura, Shōichirō 杉浦正一郎, Miyamoto, Saburō 宮 本三郎 und Ogino, Kiyoshi 荻野清; Nihon koten bungaku taikei 日本古典文学大系, 46; Tōkyō: Iwanami Shoten 岩波書店, 1970): 277-294.

Takeda, Izumo Nisei 竹田出雲二世 (1748): „Kanadehon Chūshingura 仮名手本忠臣蔵“. In: Jōruri shū 浄瑠璃集, 1 (Hgg. Otoba, Hiromu 乙葉弘 und Tsurumi, Makoto 鶴見誠; Nihon koten bungaku taikei 日本古典文学大系, 51; 7. Aufl. Tōkyō: Iwanami Shoten 岩波書店, 1969): 291-382.

Toneri, Shinnō 舎人親王 (720): Nihon shoki 日本書紀. Hgg. Sakamoto, Tarō 坂本太郎, lenaga, Saburō 家永三郎, Inoue, Mitsusada 井上光貞 und Ōno, Susumu 大野晋. (Nihon koten bungaku taikei 日本古典文学大系, 67-68). 4. Aufl. Tōkyō: Iwanami Shoten 岩波書店, 1970.

Tsubouchi, Shōyō 坪内逍遥 (1885): „Ichidoku santan Tōsei shosei katagi 一読三歎当世書生気 質“. In: Tsubouchi Shōyō shū 坪内逍遥集 (Hgg. Nakamura, Kan 中村完 und Umezawa, Nobuo 梅澤宣夫; Nihon kindai bungaku taikei 日本近代文学大系, 3; Tōkyō: Kadokawa Shoten 角川書店, 1974): 221-433.

Uejima, Onitsura 上島鬼貫 (1718): „Hitorigoto 独こと“. In: Onitsura zenshū 鬼貫全集 (Tōkyō: Kadokawa Shoten 角川書店, 1968): 184-206.

Wei, Shuzi 魏叔子 (1681): „Da Shiyu shan shi dushu 答施愚山侍読書“. In: Wei Shuzi wenji 魏 叔子文集: 22 juan 二十二卷: Rilu 8 juan 日冈八卷 (Taibei 臺北: Taiwan Shangwu Yinshuguan 臺灣商務印書館, 1973): 719-724.

Wei, Shuzi 魏叔子 (1681): „Zong Zi fawen ji xu 宗子發文集序“. In: Wei Shuzi wenji 魏叔子文集: 22 juan 二十二卷: Rilu 8 juan 日冈八卷 (Taibei 臺北: Taiwan Shangwu Yinshuguan 臺灣商 務印書館, 1973): 1023-1027.

Xu, Shiceng 徐師曾 (1852): Wenti mingbian 文体明弁. Wakokubon Buntai meiben 和刻本 - 文 体明弁 (4 Bde.). Kyōto 京都: Chūbun Shuppansha 中文出版社, 1982.

Yijing 易経 (3. Jahrtausend v.Chr.): Eki kyō 易経, 3. Bde. Hg. Imai, Usaburō 今井宇三郎. 8. Aufl. (Shinshaku kanbun taikei 新釈漢文大系, 23; 24; 63). Tōkyō: Meiji Shoin 明治書院, 2001-2008.

Yu, Zhi 余治 (1869): Deyi lu 得一録. Ort und Verlag unbekannt.

Zeami, Motokiyo 世阿弥元清 (1423): „Yūgaku shūdō fūken 遊楽習道風見“. In: Karon shū 歌論集 - Nōgakuron shū 能楽論集 (Hgg. Hisamatsu, Sen’ichi 久松潜一 und Nishio, Minoru 西尾実; Nihon koten bungaku taikei 日本古典文学大系, 65; 10. Aufl. Tōkyō: Iwanami Shoten 岩波書店, 1969): 439-446. 
Zeami, Motokiyo 世阿弥元清 (1481): „Fūshi kaden 風姿花伝“. In: Karon shū 歌論集 -

Nōgakuron shū 能楽論集 (Hgg. Hisamatsu, Sen’ichi 久松潜一 und Nishio, Minoru 西尾実; Nihon koten bungaku taikei 日本古典文学大系, 65; 10. Aufl. Tōkyō: Iwanami Shoten 岩波 書店, 1969): 341-398.

Zhiyi 智顗 (ca. 594): Mohe zhiguan 摩訶止観. Shōkai Maka shikan 詳解摩訶止観. Bearb. Ikeda, Rosan 池田魯参. Tōkyō: Taizō Shuppan 大蔵出版, 1996.

Zhou, Bi 周怩 (1250): Sandi shi 三体詩. Santai shi hō 三體詩法 (1653-1657). Hg. Enshi 円至. Kyōto 京都: Tawara Nizaemon 田原仁左衛門.

Zhou, Bi 周饴 (1250): Sandi shi 三体詩. Santai shi 三体詩. Hg. Murakami, Tetsumi 村上哲見; Chūgoku koten sen 中国古典選, 29-32; Tōkyō: Asahi Shinbun sha 朝日新聞社, 1978.

Zhou, Bi 周怩 (1250): Sandi shi 三体詩. Zōchū Tōken zekku santai shi hō 増註唐賢絶句三體詩 法 (1494). (3 Bde.) Izumi 和泉: Sennan 泉南; Asaino Sōtei 阿佐井野宗禎, 1494.

Zhou, Bi 周㢱 (1250): Sandi shi 三体詩. Zōchū Tōken zekku santai shi hō 増註唐賢絶句三體詩 法 (1718). Hg. Hayashi, Razan 林羅山. Edo 江戸: Gan'eidō 含英堂; Meiseidō 明誠堂, 1718.

Zhu, Xi 朱喜 und Li, Jingde 黎靖徳 (1270): Lunwen 論文. In: Wakokubon Shushi gorui taizen 和刻 本朱子語類大全. (8 Bde.). Kyōto 京都: Chūbun Shuppansha 中文出版社, 1973): 6869-6964.

Zhuang, Zhou 荘周 (ca. 280 v.Chr.): Zhuangzi 荘子. Sōji 荘子. In: Rōshi 老子 - Sōji 荘子: Jō 上 und Sōji 荘子. Hgg. Ichikawa, Yasushi 市川安司 und Endō, Tetsuo 遠藤哲夫. (Shinshaku kanbun taikei 新釈漢文大系, 7-8). Tōkyō: Meiji Shoin 明治書院, 1985.

\subsection{Sekundärliteratur}

Hier werden nur die direkt oder indirekt zitierte Forschungsliteratur sowie Übersetzungsliteratur zum Thema der vorliegenden Abhandlung aufgeführt.

Ackermann, Peter (2000): Die vier Jahreszeiten: Gedichte aus dem Kokin wakashū. Frankfurt am Main: Insel Verlag.

Akutagawa, Ryūnosuke 芥川龍之介 und Putz, Otto (1997): Das Leben eines Narren. (Bibliothek Suhrkamp, 1254). Frankfurt am Main: Suhrkamp.

Akutagawa, Ryūnosuke 芥川龍之介 und Yoshida, Seiichi 吉田精一 (1927): „Aru ahō no isshō 或る阿呆の一生“. In: Akutagawa Ryūnosuke shū 芥川龍之介集 (38): 241-265.

Ames, Roger T. (1993): Sun-Tzu the Art of Warfare: The First English Translation Incorporating the Recently Discovered Yin-Ch'Üeh-Shan Texts. (Classics of ancient China). New York: Ballantine Books.

Antoni, Klaus J. (2012): Kojiki - Aufzeichnung alter Begebenheiten. Berlin: Verlag der Weltreligionen.

Aoki, Masaru 青木正児 (1943): Shina bungaku shisō shi 支那文學思想史. Tōkyō: Iwanami Shoten 岩波書店.

Árokay, Judit (2010): Die Erneuerung der poetischen Sprache: Poetologische und sprachtheoretische Diskurse der Edo-Zeit. Judit Árokay / Zugl. überarb. Fassung von: Berlin, Freie Univ., Habil.-Schr., 2007. (Iaponia insula, 24). München: iudicium Verlag.

Aston, William George (1978): Nihongi - Chronicles of Japan from the earliest times to A.D. 697: Translated from the original Chinese and Japanese by W.G. Aston, C.M.G. 4. Aufl. London: Kegan Paul, Trench, Trübner \& Co. Ltd., 1978. 
Asō, Yoshiteru 麻生義輝 (1942): Kinsei Nihon tetsugaku shi 近世日本哲学史. Tōkyō: Kondō Shoten 近藤書店.

Balmes, Sebastian (2015): Die rituelle Errettung der Murasaki Shikibu: Buddhistische GenjiZeremonien und ihre Spuren in der japanischen Kulturgeschichte. (Münchner Schriftenreihe Japanforschung, Bd. 1). Bochum: Projektverlag.

Balmes, Sebastian (2017): „,,Verrückte Sprache und ausgeschmückte Worte“ - Zum buddhistischen Diskurs über den Wert der Literatur im Rahmen der Genji-Rezeption des 12. Jahrhunderts“. In: Bunron 文論, (4): 1-33. doi: 10.11588/BR.2017.4.1241.

Barnhill, David Landis (2005): Bashō's journey: The literary prose of Matsuo Bashō. New York, N.Y.: State University of New York Press.

Bauer, Wolfgang (2001): Geschichte der chinesischen Philosophie: Konfuzianismus, Daoismus, Buddhismus. München: C.H. Beck'sche Verlagsbuchhandlung.

Beasley, William G. (1989): „The foreign threat and the opening of the ports“. In: The Nineteenth Century (Hg. Jansen, Marius B; The Cambridge History of Japan, 5): 259-307. Cambridge: Cambridge University Press.

Benl, Oskar (1951): Die Entwicklung der japanischen Poetik bis zum 16. Jahrhundert. (Abhandlungen aus dem Gebiet der Auslandskunde, Reihe B, 31). Hamburg: Cram, De Gruyter \& Co., 1951.

Bodman, Richard Wainwright (1988): Poetics and Prosody in Early Medieval China: A study and translation of Kūkai's Bunkyō Hifuron. Ann Arbor: University Microfilms International (UMI).

Bolitho, Harold (1989): „The Tempō crisis“. In: The Nineteenth Century (Hg. Jansen, Marius B.; The Cambridge History of Japan, 5): 116-167. Cambridge: Cambridge University Press.

Bourdaghs, Michael K., Ueda, Atsuko and Murphy, Joseph A. (2009): Theory of Literature and Other Critical Writings. (Weatherhead books on Asia). New York: Columbia University Press, 2010.

Brown, Delmer M. (1993): Ancient Japan. Cambridge: Cambridge University Press (The Cambridge History of Japan, Vol. 1).

Buck-Albulet, Heidi (2005): Emotion und Ästhetik: Das “Ashiwake obune" - eine Waka-Poetik des jungen Motoori Norinaga im Kontext dichtungstheoretischer Diskurse des frühneuzeitlichen Japan. Univ., Diss.-Tübingen, 2002. (Izumi, 9). Wiesbaden: Harrassowitz Verlag.

Buck-Albulet, Heidi (2008): „Konzepte des Uneigentlichen in der klassischjapanischen Rhetorik im Mittelalter und in der frühen Neuzeit“. In: Nachrichten der Gesellschaft für Natur- und Völkerkunde Ostasiens e.V. (183-184): 75-92.

Burns, Susan L. (2003): Before the Nation: Kokugaku and the Imagining of Community in Early Modern Japan. (Asia-Pacific). Durham [N.C.]: Duke University Press.

Cai, Zong-qi (Hg.) (2001): A Chinese Literary Mind: Culture, Creativity, and Rhetoric in Wenxin Diaolong. Stanford: Stanford University Press.

Chan, Lois Mai (1972): „The Burning of the Books in China, 213 B.C.“. In: The Journal of Library History (7-2 (Apr. 1972): 101-108.

Chang, Ruth H. (2000): Understanding Di and Tian: Deity and Heaven from Shang to Tang Dynasties. (Sino-Platonic Papers, 108 (Sept. 2000)). Philadelphia: University of Pennsylvania Press.

Chan, Wing-Tsit (1963): A Source Book in Chinese Philosophy. 2. Aufl. Princeton (N.J.): Princeton University Press, 1970. 
Cleary, Thomas (Hg.) (1994): „Cultivation of Contemplation of the Inner Meaning of the Huayen: The Ending of Delusion and Return to the Source". In: Entry into the Inconceivable (Honolulu: University of Hawai'i Press, 1994): 147-169.

Craig, Albert M. (2009): Civilization and Enlightenment: The Early Thought of Fukuzawa Yukichi. Cambridge, Massachusetts: Harvard University Press.

Crowley, Cheryl (1995): „Putting Makoto into Practice: Onitsura’s Hitorigoto“. In: Monumenta Nipponica (50.1): 1-46.

Currie, Gregor (1985): „Was ist fiktionale Rede?““. In: Fiktion, Wahrheit, Wirklichkeit: Philosophische Grundlagen der Literaturtheorie (Hg. Reicher, Maria E.; KunstPhilosophie, 8; Paderborn: Mentis-Verlag, 2007): 37-53.

De Bary, William Theodore, Keene, Donald und Tsunoda, Ryūsaku (Hgg.) (1958): Sources of Japanese tradition (2 Bde.). New York: Columbia University Press, 1958.

Debon, Günther (1984): „Literaturtheorie und Literaturkritik Chinas“. In: Ostasiatische Literaturen (Hgg. Debon, Günther und Bauer, Wolfgang). (Neues Handbuch der Literaturwissenschaft, Bd. 23): 39-61. Wiesbaden: AULA-Verlag.

Dykstra, Yoshiko Kurata (2004): The Senjūshō: Buddhist Tales of Early Medieval Japan. Honolulu, Hawaii: Kanji Press.

Elman, Benjamin A. (2013): Civil Examinations and Meritocracy in Late Imperial China. Cambridge, Massachusetts: Harvard University Press.

Fujihira, Haruo 藤平春男 (1965): „Nihon no bungaku riron 日本の文学理論: Kodai kara chūsei e 古代から中世へ“. In: Bungaku ron josetsu 文学論序説: Rekishi teki tenbō to gendai no hōhō ron 歴史的展望と現代の方法論 (Hgg. Fujihira, Haruo 藤平春男, Ōsawa, Minoru 大沢 実 und Iwase, Kō 岩瀬孝; Tōkyō: Shūjusha 冬樹社): 13-59.

Fujii, Mihoko 藤井美保子 (2015): „Morikawa Kyoroku “Wakun Santai shi” 森川許六『和訓三体 詩』: ‘Jo' to ‘shi'i’「序」と「詩意」 “[Santi shi]. In: Seikei kokubun 成蹊国文 (48): 12-21.

Fung, Yu-Lan and Bodde, Derk (1983): A History of Chinese Philosophy (2 Bde.). Princeton, N.J.: Princeton University Press.

Gethmann-Siefert, Annemarie (2005): Einführung in Hegels Ästhetik. (Uni Taschenbücher, 2646). München: Finck.

Giles, Lionel (2004): On the art of war: The Oldest Military Treatise in the World. Translated from the Chinese with introduction and critical notes. London: Luzac.

Gotō, Nobuko 後藤延子 (1991): „Shushigaku no seiritsu to bukkyō 朱子学の成立と仏教“. In: Jinbun Kagaku Ronshū 人文科学論集 (25): 1-26.

Gu, Ming Dong (2006): Chinese Theories of Fiction: A Non-Western Narrative System. (SUNY series in Chinese philosophy and culture). Albany, NY: State University of New York Press.

Hall, John Whitney (1974): „Feudalism in Japan - A Reassessment“. In: Feudalismus: Zehn Aufsätze (Hg. Wunder, Heide; nympenburger texte zur wissenschaft, 17): 140-182.

Hamashita, Masahiro 浜下昌宏 (2002): „Nishi Amane on Aesthetics: A Japanese version of Utilitarian Aesthetics“. In: Japanese Hermeneutics: Current Debates on Aesthetics and Interpretation (Hg. Marra, Michael F.; Honolulu, Hawaii: University of Hawai 'i Press): 89-96.

Hamasumi, Mayu 濱住真有 (2010): „Edo jidai ni okeru Chūgoku kaiga juyō no mondai 江戸時 代における中国絵画受容の問題: Ike Taiga no kanki ni mirareru “shai” wo megutte 池大雅 の款記に見られる「写意」をめぐって“. In: Mochikaneyama ronsō 待兼山論叢 - Bigaku hen 美学篇 (44): 1-27.

Hammitzsch, Horst (1953): „Ein Reisetagebuch des Matsuo Bashō: Wegpoesie aus dem Jahre Kasshi“. In: Nachrichten der Gesellschaft für Natur- und Völkerkunde Ostasiens e.V. (75 (1953): 3-24. 
Harootunian, Harry D. (1988): Things seen and unseen: Discourse and ideology in Tokugawa nativism. Chicago: University of Chicago Press.

Hasegawa, Izumi 長谷川泉 (1966): Kindai Nihon bungaku hyōron shi 近代日本文学評論史: Kaitei ban 改訂版. 2. Aufl. (Yūseidō sensho 有精堂選書). Tōkyō: Yūseidō Shuppan 有精堂 出版, 1969.

Hata, Yūzō 畑有三 (1965): „Futabatei Shimei 二葉亭四迷: ‘Shinri’ tankyū to bungakusha no seiritsu「真理」探究と文学者の成立“. In: Nihon bungaku 日本文学 (14.11 (1965.11): 1-9.

Hata, Yūzō 畑有三 (1988): „Reimei no bungaku 黎明の文学: Kinsei kara kindai e 近世から近代 へ“. In: Nihon bungaku kōza 6 日本文学講座 6: Kindai shōsetsu 近代小説 (Hg. Izu, Toshihiko 伊豆利彦; Nihon bungaku kōza 日本文学講座, 6; Tōkyō: Taishūkan Shoten 大修 館書店): 59-76.

Havens, Thomas R.H. (1970): Nishi Amane and Modern Japanese Thought. Princeton (N.J.): Princeton University Press.

Hida, Akihiro 肥田明啓 (1999): „Hirose Tansō no shiron to sono genryū 廣瀬淡窗の詩論とその 源流: Shin jidai zenki no shiron no juyō wo chūshin to shite 清代前期の詩論の受容を中心 として“. In: Gakurin 学林 (30): 91-114.

Hida, Akihiro 肥田明啓 (2000): „Hirose Tansō no shiron to Kangi’en kyōiku to no kanren 廣瀬淡 窗の詩論と咸宜園教育との關連“. In: Ritsumeikan Bungaku 立命館文學 (563): 1061-1079.

Hijikata, Teiichi 土方定一 (1937): Kindai Nihon bungaku hyōron shi 近代日本文学評論史. (Nihon bungaku kenkyū kihon sōsho 日本文学研究基本叢書). Tōkyō: Hōsei Daigaku Shuppan Kyoku 法政大学出版局, 1973.

Hijiya-Kirschnereit, Irmela (1979): „Theoriedefizit und Wertungswut: Die nicht existenten Probleme der modernen japanischen Literaturgeschichtsschreibung (2)“. In: Bochumer Jahrbuch zur Ostasienforschung (2 (1979): 286-306.

Hirakawa, Sukehiro 平川祐弘 (1989): „Japan's turn to the West: A Consciousness of Self in Meiji Youth: The Reaction Against Slavish Westernization“. In: The Nineteenth Century (Hg. Jansen, Marius B.; The Cambridge History of Japan, 5): 432-498. Cambridge: Cambridge University Press.

Hiroshima, Kazuo 広島一雄 (1967): Kindai Nihon bungaku hyōron shō 近代日本文学評論抄. Tōkyō: Honami Shuppansha 穂波出版社.

Hirota, Jirō 広田二郎 (1961): „Danrin ha no gūgen setsu to Bashō 談林派の寓言説と芭蕉“. In: Jinbun kenkyū 人文研究 (21-22 (Aug. 1961): 673-708.

Hisamatsu, Sen'ichi 久松潜一 (1941): Nihon bungaku hyōron shi 日本文學評論史: Kinsei - sai kinsei hen 近世・最近世篇. 7. Aufl. Tōkyō: Shibundō 至文堂.

Hisamatsu, Sen'ichi 久松潜一 (1952): Nihon bungaku hyōron shi 日本文學評論史: Kinsei kindai hen 近世・近代篇. Tōkyō: Shibundō 至文堂.

Hisamatsu, Sen'ichi 久松潜一 (1963): Nihon karon shi no kenkyū 日本歌論史の研究. Tōkyō: Kazama Shobō 風間書房.

Hisamatsu, Sen'ichi 久松潜一 (1963): The Vocabulary of Japanese Literary Aesthetics. Tōkyō: Center for East Asian Cultural Studies.

Hisamatsu, Sen'ichi 久松潜一 (1969): Nihon bungaku hyōron shi 日本文学評論史: Rinen hyōgen ron hen 理念 - 表現論篇. (Hisamatsu Sen'ichi chosaku shū 久松潜一著作集, 10). Tōkyō: Shibundō 至文堂.

Hisamatsu, Sen'ichi 久松潜一 (1977): Zōho Shinpan Nihon bungaku shi 増補新版日本文学史. 7 Bde. Tōkyō: Shibundō 至文堂.

Honma, Hisao 本間久雄 (1935): Shintei Meiji bungaku shi 新訂明治文学史: Fukkoku ban 復刻 版. 2 Bde. (Nihon bungaku zenshi 日本文学全史, 10-11). Tōkyō: Tōkyōdō 東京堂, 1994. 
Horikiri, Minoru 堀切実 (1968): „Shikō no kyojitsu ron no tenkai 支考の虚実論の展開“. In: Kinsei bungei 近世文芸 (14 (Juni 1968): 26-37.

Hsiao, Li-Ling (2013): „Wang Wei’s and Su Shi's Conceptions of “Painting within Poetry”“. In: Southeast Review of Asian Studies (35): 178-189.

Hughes, Ernest Richard (1951): The art of letters: Lu Chi's 'Wen fu', A. D. 302: A Translation and Comparative Study. Princeton (N.J.): Princeton University Press.

Ikeda, Sadao 池田貞男 (1943): „Bashō no kyojitsu ron 芭蕉の虚実論“. In: Nihon bungakushi ni okeru bungaku ron 日本文学史に於ける文学論 (Hg. Yoshida, Kōichi 吉田幸一; Tōkyō: Tōyō Daigaku 東洋大学): 283-392.

Ikegami, Eiko (1997): The taming of the Samurai: Honorific individualism and the making of modern Japan. 4. Aufl. Cambridge Mass. u.a.: Harvard University Press, 2001.

Imoto, Nōichi 井本農一 (1961): „Kaisetsu 解説“. In: Renga ron shū 連歌論集 - Hairon shū 俳論 集 (Hgg. Kidō, Saizō 木藤才蔵 und Imoto, Nōichi 井本農一; Nihon koten bungaku taikei 日 本古典文学大系, 66). Tōkyō: Iwanami Shoten 岩波書店.

Inada, Hide Ikehara (1968): „Translators and Translations of the Meiji Era“. In: Japan's modern century: A special issue of Monumenta Nipponica prepared in celebration of the centennial of the Meiji restoration (Hg. Skrzypczak, Edmund R.; Tōkyō: Charles E. Tuttle): 133-159.

Inaga, Shigemi (2002): „Cognitive Gaps in the Recognition of Masters and Masterpieces in the Formative Years of Japanese Art History, 1880-1900: Historiography in Conflict“. In: Japanese Hermeneutics: Current Debates on Aesthetics and Interpretation (Hg. Marra, Michael F.; Honolulu, Hawaii: University of Hawai'i Press): 114-126.

Inoue, Minoru 井上豊 (1966): „Kyojitsu ron no shosō 虚実論の諸相“. In: Bunkei ronsō 文経論 叢 (1966.12): 1-22.

Inoue, Minoru 井上豊 (1968): „Nihon bungaku no shōchōsei to kyojitsu 日本文学の象徵性と 虚実“. In: Bunkei ronsō 文経論叢 (3 (3): 1-18.

Iser, Wolfgang (1970): Die Appellstruktur der Texte. 4. Aufl. (Konstanzer Universitätsreden, 28). Konstanz: Universitätsverlag Konstanz GmbH, 1974.

Iser, Wolfgang (1975): „Die Wirklichkeit der Fiktion“. In: Rezeptionsästhetik: Theorie und Praxis (Hg. Warning, Rainer; Uni Taschenbücher, 303; München: Wilhelm Fink Verlag): 277-324.

Iser, Wolfgang (1983): „Das Imaginäre: Kein isolierbares Phänomen“. In: Funktionen des Fiktiven (Hgg. Henrich, Dieter und Iser, Wolfgang; Poetik und Hermeneutik, 10; München: Fink): 479-486.

Iser, Wolfgang (1993): Das Fiktive und das Imaginäre: Perspektiven literarischer Anthropologie. (Suhrkamp-Taschenbuch Wissenschaft, 1101). Frankfurt am Main: Suhrkamp.

Iser, Wolfgang (1976): Der Akt des Lesens: Theorie ästhetischer Wirkung. 4. Aufl. (Uni Taschenbücher, 636). München: Wilhelm Fink Verlag, 1994.

Isogai, Hideo 磯貝英夫 (1962): „Sōjitsu ron no tenkai 想実論の展開: Ningetsu - Ōgai - Tōkoku 忍月・鴎外・透谷“. In: Kokubungaku kō 国文学放 (28 (Mai 1962): 290-299.

Itasaka, Noriko 板坂則子 (2010): Kyokutei Bakin no sekai 曲亭馬琴の世界: Gesaku to sono shūen 戯作とその周縁. Tōkyō: Kasama Shoin 笠間書院.

Iwatsu, Motoo 岩津資雄 (1954): „Kajitsu ron 花実論: Karon shi kenkyū josetsu 歌論史研究序 説“. In: Nihon bungaku ronkō 日本文学論放: Kubota Utsubo sensei kiju kinen ronshū 窪田 空穂先生喜寿記念論集 (Hg. Toki, Zenmaro 土岐善麿; Tōkyō: Waseda Daigaku Kokubungaku Kai 早稲田大学国文学会): 771-786.

Jahraus, Oliver (2004): Literaturtheorie: Theoretische und methodische Grundlagen der Literaturwissenschaft. Tübingen [u.a.]: Francke Verlag. 
Jansen, Marius B. (1989): „The Meiji Restoration“. In: The Nineteenth Century (Hg. Jansen, Marius B.). (The Cambridge History of Japan, 5; Cambridge: Cambridge University Press): 308-366.

Jauß, Hans Robert (1993): „Literaturgeschichte als Provokation der Literaturwissenschaft. In: Literaturgeschichte als Provokation (Frankfurt am Main: Suhrkamp): 144-207.

Kambayashi, Tsunemichi (2002): „Ōgai, Schelling, and Aesthetics“. In: Japanese Hermeneutics: Current Debates on Aesthetics and Interpretation (Hg. Marra, Michael F.; Honolulu, Hawaii: University of Hawai'i Press): 109-114.

Kamei, Takashi 亀井孝 (1975): Nippo jisho 日葡辞書: Vocabvlario da lingoa de lapam. Tōkyō: Benseisha 勉誠社.

Kamijō, Shōji 上条彰次 (1985): „Shiika ron 1 詩歌論 1 : Kodai chūsei karon 古代中世歌論“. In: Nihon koten bungaku hyōron shi 日本古典文学評論史 (Hg. Fukui, Teisuke 福井貞助; Tōkyō: Ōfūsha 桜楓社): 9-54.

Kaneda, Tamio 金田民夫 (2001): „Fenollosa and Tsubouchi Shōyō“. In: A history of modern Japanese aesthetics (Hg. Marra, Michael F.; Honolulu: University of Hawai i Press): 53-67.

Katagami, Noburu 片上伸 (1926): „Bungaku no dokusha no mondai 文学の読者の問題“. In: Katagami Noburu zenshū 片上伸全集 (Hg. Katagami, Shintarō片上晨太郎): 188-201.

Katō, Hilda (1968): „The Mumyōshō“. In: Monumenta Nipponica (XXIII-3/4): 351-430.

Katō, Hilda (1968): „The Mumyōshō of Kamo no Chōmei and Its Significance in Japanese Literature“ [Katō 1968 a]. In: Monumenta Nipponica (XXIII-3/4): 321-349.

Kawazoe, Kunimoto 川副国基 (1977): Kindai bungaku no hyōron to sakuhin 近代文学の評論と 作品. Tōkyō: Waseda Daigaku Shuppanbu 早稲田大学出版部.

Keene, Donald (1971): Chūshingura: The Treasury of Loyal Retainers: A puppet play by Takeda Izumo, Miyoshi Shōraku, and Namiki Senryū. New York: Columbia University Press.

Keene, Donald (1978): World within walls: Japanese literature of the Pre-Modern Era, 16001867. New York: Holt, Rinehart and Winston.

Keene, Donald (1984): Dawn to the West: Japanese Literature in the Modern Era (2 Bde.). New York: Holt, Rinehart and Winston.

Keene, Donald (1993): Seeds in the heart: Japanese literature from earliest times to the late sixteenth century. New York: Henry Holt \& Co.

Kibata, Sadakiyo 木畑貞清 (1935): Kimura Mokurō to Takizawa Bakin 木村黙老と滝沢馬琴. Takamatsu 高松: Kagawa Ken Kyōiku Tosho 香川県教育図書.

Kimura, Miyogo 木村三四五 (1983): „Mokurō ate Bakin shokan 黑老宛馬琴書翰: Tenpō 3 nen 8 gatsu 26 nichi 天保三年八月二十六日“. In: Biburia ビブリア - Biblia (80 (04.1983): 22-47.

Knechtges, David R. (526-531): Wen xuan, or, Selections of refined literature (3 Bde.). (Princeton Library of Asian Translations). Princeton, N): Princeton University Press, 1982-1996.

Kohn, Livia (1995): „Taoism in Japan: Positions and Evaluations“. In: Cahiers d'Extrême-Asie (8): 389-412.

Köhn, Stephan (2002): “Berichte über Gesehenes und Gehörtes aus der Ansei-Zeit” (Ansei kemmonshi): Kanagaki Robuns (1829-1894) Bericht über das grosse Ansei-Erdbeben 1855 als Repräsentant des Genres der "Katastrophendarstellungen". (Bunken, 7). Wiesbaden: Harrassowitz Verlag.

Konishi, Jin’ichi 小西甚一 (1946): „Fueki ryūkō setsu no genkei 不易流行説の原型“. In: Kokugo kokubun 国語国文 (14.10 (Jan. 1946): 28-39.

Konishi, Jin'ichi 小西甚一 (1946): „Shina bungei no kyojitsu ron 支那文芸の虚実論“. In: Kokubungaku kaishaku to kanshō 国文学解釈と鑑賞 (11.3): 23-28. 
Konishi, Jin’ichi 小西甚一 (1963): „'Kamo no koe honoka ni shiroshi ‘「鴨の声ほのかに白 し」: Bashō ku bunseki hihyō no kokoromi 芭蕉句分析批評の試み“. In: Bungaku 文学 (31.8): 1-14.

Konta, Yōzō 今田洋三 (1981): Edo no kinsho 江戸の禁書. (Edo sensho 江戸選書, 6). Tōkyō: Yoshikawa Kōbun Kan 吉川弘文館.

Kornicki, Peter Francis (1977): „Nishiki no Ura: An Instance of Censorship and the Structure of a Sharebon“. In: Monumenta Nipponica (32.2): 153-188.

Kracht, Klaus (1986): Studien zur Geschichte des Denkens im Japan des 17. bis 19. Jahrhunderts: Chu-Hsi-konfuzianische Geist-Diskurse. (Veröffentlichungen des OstasienInstituts der Ruhr-Universität Bochum, Bd. 31). Wiesbaden: Otto Harrassowitz.

Kubota, Yoshitarō 久保田芳太郎 (1979): „Botsu risō ronsō wo megutte 没理想論争をめぐって: Mōruton to Harutoman モールトンとハルトマン“. In: Tsubouchi Shōyō - Futabatei Shimei 坪内逍遥・二葉亭四迷 (Hg. Nihon Bungaku Kenkyū Shiryō Kankōkai 日本文学研究資料刊 行会; Nihon bungaku kenkyū kihon sōsho 日本文学研究基本叢書; Tōkyō: Yūseidō Shuppan 有精堂出版): 97-105.

Legge, James (1885): The Lī Kĩ: I-X. (The Sacred Books of China: The Texts of Confucianism, 27). London: Clarendon Press.

Legge, James (1891): The Tao Teh King - The Writings of Kwang Zze I-XVII. (The Sacred Books of China: The Texts of Taoism, 1). Oxford: Clarendon Press.

Legge, James (1900): „The Works of Mencius“. In: The Four Books: Confucian Analects, The Great Learning, The Doctrine of the Mean, and The Works of Mencius (Shanghai: The Commercial Press): 429-1014.

Levy, Dore J. (2001): „Literary Theory and Criticism“. In: The Columbia History of Chinese Literature (Hg. Mair, Victor H.; New York: Columbia University Press): 916-939.

Lewin, Bruno (1990): „Mori Ōgai und die deutsche Ästhetik“. In: japanstudien, 1: 271-296. Lima, Luiz Costa, Kretschmer, Johannes and Spielmann, Ellen (2012): Mimesis: Herausforderung an das Denken. Berlin: Kulturverlag Kadmos.

Link, Jürgen (1974): Literaturwissenschaftliche Grundbegriffe: Eine programmierte Einführung auf strukturalistischer Basis. 3. Aufl. München: Wilhelm Fink Verlag, 1985.

Linzbichler, Gerhardt (1971): Fukuzawa Yukichi: Eine autobiographische Lebensschilderung. Fukuō jiden. Tōkyō: Deutsch-Japanische Gesellschaft.

Liu, James J. Y. (1975): Chinese theories of literature. Chicago: University of Chicago Press. $\mathrm{Li}$, Zhaochu (2007): Wenxin diaolong: Das literarische Schaffen ist wie das Schnitzen eines Drachens. Bochum: Projekt Verlag.

Shih, Vincent Yu-chung (1959): The Literary Mind and the Carving of Dragons by Liu Hsieh: A Study of Thought and Pattern in Chinese Literature. (Records of Civilization - Sources and Studies). New York: Columbia University Press, 1959.

Lukács, Georg (1963): Die Eigenart des Ästhetischen (2 Bde.). Berlin: Aufbau-Verlag, 1981. Machida, Saburō 町田三郎 (1998): Edo no kangakusha tachi 江戸の漢学者たち. Tōkyō: Kenbun Shuppan 研文出版.

Maeda, Ai 前田愛 (1969): „Kinsei kara kindai e 近世から近代へ: Aizan - Tōkoku no bungaku shi wo megutte 愛山・透谷の文学史をめぐって“. In: Bakumatsu ishin ki no bungaku 幕 末維新期の文学: 3-23.

Maeda, Ai 前田愛 (1973): „Dokusha ron shōshi 読者論小史“. In: Kindai dokusha no seiritsu 近 代読者の成立 (Tōkyō: Yūseidō Shuppan 有精堂出版, 1993): 312-373.

Maeda, Ai 前田愛 (1969): „Meiji shonen no dokusha zō 明治初年の読者像“. In: Kindai dokusha no seiritsu 近代読者の成立 (Tōkyō: Yūseidō Shuppan 有精堂出版, 1993): 147-166. 
Maeda, Ai 前田愛 (1962): „Ondoku kara mokudoku e 音読から黙読へ: Kindai dokusha no seiritsu 近代読者の成立“. In: Kindai dokusha no seiritsu 近代読者の成立 (Tōkyō: Yūseidō Shuppan 有精堂出版, 1993): 167-220.

Maeda, Tsutomu 前田勉 (2012): Edo no dokusho kai 江戸の読書会: Kaidoku no shisō shi 会読 の思想史. (Heibonsha sensho 平凡社選書, 232). Tōkyō: Heibonsha 平凡社.

Mair, Victor H. (Hg.) (1994): The Columbia anthology of traditional Chinese literature: Texts translated from the Chinese. New York: Columbia University Press (Translations from the Asian classics).

Mair, Victor H. und Schuhmacher, Stephan (1998): Zhuangzi: Das klassische Buch daoistischer Weisheit. Frankfurt am Main: Wolfgang Krüger Verlag.

Makibayashi, Kōji 槙林滉二 (1984): „Kyojitsu no roku kaitei 虚実の六階梯: Shōnan 小南 Sohō 蘇峰 - Tōkoku 透谷“. In: Kitamura Tōkoku to Tokutomi Sohō 北村透谷と徳富蘇峰 (Hg. Yamazaki, Makoto 山崎誠; Shin'ei kenkyū sōsho 新鋭研究叢書, 1; Tōkyō: Yūseidō Shuppan 有精堂出版): 126-152.

Marra, Michael F. (2001): A history of modern Japanese aesthetics (2001): Honolulu: University of Hawai'i Press.

Marra, Michael F. (2002) Japanese Hermeneutics: Current Debates on Aesthetics and Interpretation. Honolulu, Hawaii: University of Hawai'i Press.

Maruyama, Masao 丸山真男 and Hane, Mikiso (1974): Studies in the Intellectual History of Tokugawa Japan. Princeton (N.J.): Princeton University Press.

Matsuo, Yasuaki 松尾靖秋 (1954): „Kyojitsu ni kan suru nōto 虚実に関するノート: Bashō no kyojitsu kan to no kanren ni oite 芭蕉の虚実観との関聯において“. In: Nihon bungaku ronkō 日本文学論放: Kubota Utsubo sensei kiju kinen ronshū 窪田空穂先生喜寿記念論集 (Hg. Toki, Zenmaro 土岐善榣; Tōkyō: Waseda Daigaku Kokubungaku Kai 早稲田大学国文 学会): 457-470.

May, Ekkehard (1983): Die Kommerzialisierung der japanischen Literatur in der späten EdoZeit (1750-1868): Rahmenbedingungen und Entwicklungstendenzen der erzählenden Prosa im Zeitalter ihrer ersten Vermarktung. Ekkehard May / Zugl.: Bochum, Univ., Habil.Schr., 1979. Wiesbaden: Harrassowitz Verlag.

May, Ekkehard (1985): „Synästhesie bei Bashō: Zu einem Aspekt der Haiku-Metaphorik“. In: Referate des VI. deutschen Japanologentages in Köln, Vl. Deutscher Japanologentag (Universität Köln - Japanologie, Köln, 12.-14. Apr. 1984. Hamburg: Gesellschaft für Naturund Völkerkunde Ostasiens e.V.): 184-190.

May, Ekkehard (1989): Bakins Zeitreise oder Wie modern ist die moderne japanische Literatur? (Vortrag Universität Köln - Japanologie am 13.06.1989).

McCullough, Helen Craig (1959): The Taiheiki: A chronicle of medieval Japan: Translated, with an Introduction and notes by Helen Craig MacCullough. Rutland, Vt: Charles E. Tuttle, 1979.

McCullough, Helen Craig (1985): Kokin Wakashū: The First Imperial Anthology of Japanese Poetry. With Tosa Nikki und Shinsen Waka. Stanford (Calif.): Stanford University Press.

Metscher, Thomas (2001): Mimesis. (Bibliothek dialektischer Grundbegriffe, 5). Bielefeld: Aisthesis.

Mikawa, Tomohisa 三川智央 (2012): „Meiji shoki no gesaku no dōkō (I) 明治初期の戯作の動向 (I): Kanagaki Robun - Jōno Denbei ni yoru Kyōbu shō e no jōshinsho wo meguru kōsatsu 仮名垣魯文・条野伝平による教部省への上申書をめぐる考察“. In: Ningen shakai kankyō $k e n k y \bar{u}$ 人間社会環境研究 (24): 141-154. 
Mikawa, Tomohisa 三川智央 (2013): „Meiji shoki no gesaku no dōkō (II) 明治初期の戯作の動 向 (II): “Jitsu” to iu kachikan wo megutte〈実〉という価值観をめぐって“. In: Ningen shakai kankyō kenkyū 人間社会環境研究 (25): 125-137.

Mikawa, Tomohisa 三川智央 (2013): „Meiji shoki no gesaku no dōkō (III) 明治初期の戯作の動 向 (III): Jijitsu sei e no shikō 事実性への志向“. In: Ningen shakai kankyō kenkyū 人間社会 環境研究 (26): 137-151.

Mimura, Shōji 三村昌司 (2008): „Kōginin no sonzai keitai to kōgisho ni okeru “giron” 公議人 の存在形態と公議所における「議論」: Mita han wo jirei ni 三田藩を事例に“. In: Rekishi gaku kenkyū 歴史学研究 (842): 33-44.

Miyamoto, Saburō 宮本三郎 (1974): „Haikai bungei ron 俳諧文芸論: Bashō to Bashō izen 芭蕉 と芭蕉以前“. In: Shōfū haikai ron kō 蕉風俳諧論考 (Kasama sōsho 笠間叢書, 43; Tōkyō: Kasama Shoin 笠間書院): 3-23.

Miyamoto, Saburō 宮本三郎 (1974): „Kyojitsu ron josetsu 虚実論序説“. In: Shōfū haikai ron kō 蕉風俳諧論考 (Kasama sōsho 笠間叢書, 43; Tōkyō: Kasama Shoin 笠間書院): 25-42.

Mizuno, Minoru 水野稔 (1974): ,Kyōden sharebon ni okeru shajitsu to sono gihō 京伝酒落本 における写実とその技法“. In: Edo shōsetsu ronsō 江戸小説論叢 (Tōkyō: Chūō Kōron Sha 中央公論社): 104-146.

Murakami, Tetsumi 村上哲見 (1994): „Kyoroku “Wakun santai shi” wo megutte 許六『和訓三 体詩』をめぐって“. In: Haikai to kanbun gaku 俳諧と漢文学 (Hg. Wakan hikaku bungaku kai 和漢比較文学会; Wakan hikaku bungaku sōsho 和漢比較文学叢書, 16; Tōkyō: Kyūko Shoin 波古書院): 167-184.

Waley, Arthur (1960): The tale of Genji: A novel in six parts, by Lady Murasaki. New York, N.Y.: The Modern Library, 1960.

Nakajima, Yōichi 中島洋一 (1966): Nihon bungei riron ni okeru shōchō teki hyōgen rinen no $k e n k y u \bar{u}$ 日本文芸理論における象徵的表現理念の研究. Tōkyō: Kazama Shobō 風間書房.

Nakamura, Shin’ichirō 中村真一郎 (1951): „Fikushon フィクション“. In: Nihon bungaku no biteki rinen 日本文学の美的理念 (Hg. Aono, Suekichi 青野季吉; Nihon bungaku kōza 日本 文学講座, 7; Tōkyō: Kawade Shobō 河出書房): 197-206.

Nakamura, Yukihiko 中村幸彦 (1958): Kinsei jusha no bungakukan 近世儒者の文学観. (Iwanami kōza Nihon bungaku shi 岩波講座日本文学史, 7). Tōkyō: Iwanami Shoten 岩波 書店.

Nakamura, Yukihiko 中村幸彦 (1961): Kinsei shōsetsushi no kenkyū 近世小説史の研究. Tōkyō: Ōfūsha 桜楓社.

Nakano, Mitsutoshi 中野三敏 (1981): Gesaku kenkyū 戯作研究. Tōkyō: Chūō Kōron Sha 中央公 論社.

Naumann, Wolfram (1963): Hitorigoto: eine Haikai-Schrift des Onitsura. (Studien zur Japanologie, 4). Wiesbaden: Harrassowitz Verlag.

Nishiyama, Matsunosuke 西山松之助 (1972): „Kinsei geidō shisō no tokushitsu to sono tenkai 近世芸道思想の特質とその展開“. In: Kinsei geidō ron 近世芸道論 (Hgg. Nishiyama, Matsunosuke 西山松之助, Watanabe, Ichirō 渡辺一郎 und Gunji, Masakatsu 郡司正勝; Nihon shisō taikei 日本思想大系, 61; Tōkyō: Iwanami Shoten 岩波書店): 585-611.

Noyama, Kashō 野山嘉正 [1978 (1988): „Kindai hihyō no seiritsu 近代批評の成立“. In: Nihon bungaku zenshi 日本文学全史: Kindai 近代 (Hgg. Miyoshi, Yukio 三好行雄, Tsutsumi, Seiji 堤清二, Akiyama, Ken 秋山虔 und Ōkubo, Tadashi 大久保正; Nihon bungaku zenshi 日本 文学全史, 5; Tōkyō: Gakutōsha 学燈社): 91-107.

Ō, Teki 王廸 (Wang, Di) (2001): Nihon ni okeru Rō Sō shisō no juyō 日本における老荘思想の受 容. Tōkyō: Kokusho Kankōkai 国書刊行会. 
Ochi, Haruo 越智治雄 (1972): „Sō jitsu ron joshō 想実論序章“. In: Bungaku 文学 (40.1 (Jan. 1972): 1-14.

Ohki, Sadako (2007): „Taiga's Ink Bamboo with Chinese Verse: Collage of Painting, Calligraphy and Poetry“. In: Ike Taiga and Tokuyama Gyokuran: Japanese Masters of the Brush (Hgg. Fischer, Felice und Kinoshita, Kyoko; Philadelphia: Philadelphia Museum of Art): 75-93.

Okamura, Keiji 岡村敬二 (2017): Edo no zōshoka tachi 江戸の蔵書家たち. Tōkyō: Yoshikawa Kōbun Kan 吉川弘文館.

Okitsu, Kaname 興津要 (1954): „Edo gesaku no matsuro“. In: Kokubungaku kaishaku to kanshō 国文学解釈と鑑賞 (19.5): 58-61.

Okitsu, Kaname 興津要 (1958): „Bakumatsu - kaika ki gesaku no dokusha sō 幕末 ・開化期戯 作の読者層“. In: Bungaku 文学 (26.5 (Mai 1958): 109-119.

Okitsu, Kaname 興津要 (1958): Edo gesaku no matsuro 江戸戯作の末路. (Iwanami kōza Nihon bungaku shi 岩波講座日本文学史, 8-4). Tōkyō: Iwanami Shoten 岩波書店.

Okitsu, Kaname 興津要 (1959): „Kinsei makki no seiji to bungei shichō 近世末期の政治と文芸 思潮“. In: Kokubungaku Kaishaku to Kyōzai no Kenkyū 国文学解釈と教材の研究 (5.11 (Sept. 1959; Kinsei bungei shichō no tankyū 近世文芸思潮の探求): 79-84.

Okitsu, Kaname 興津要 (1960): Tenkanki no bungaku 転換期の文学: Edo kara Meiji e 江戸から 明治へ. Tōkyō: Waseda Daigaku Shuppanbu 早稲田大学出版部.

Okitsu, Kaname 興津要 (1962): „Shokei kara mita shūmatsu ki no gesaku 書形から見た終末期 の戯作“. In: Gakugei kenkyū 学芸研究 (11.1962): 111-119.

Okitsu, Kaname 興津要 (1968): Meiji kaikaki bungaku no kenkyū 明治開化期文学の研究. Tōkyō: Ōfūsha 桜楓社.

Okitsu, Kaname 興津要 (1960): Saigo no Edo gesakusha tachi 最後の江戸戯作者たち. (Yūraku sensho 有楽選書, 5). Tōkyō: Jitsugyō no Nihon Sha 実業の日本社, 1976.

Okitsu, Kaname 興津要 (1983): Shinbun zasshi hassei jijō 新聞雑誌発生事情. (Kadokawa sensho 角川選書, 76). Tōkyō: Kadokawa Shoten 角川書店.

Ōmoto, Tatsuya 大本達也 (2012): „Meiji shoki ni okeru gesakusha to sono dōkō 明治初期にお ける戯作者とその動向“. The Activities of Novelists in the Early Meiji-era -A Study of “National Literature" in Japan as a "Nation State"(10)-. In: CAMPANA (19): 95-106.

Ōnuki, Toshihiko 大貫俊彦 (2008): „'Kyōkō’ na Fuchian「強硬」な不知庵: “Ukishiro monogatari” ronsō ni okeru Uchida Fuchian no ‘noveru’ no hoji 『浮城物語』論争におけ る内田不知庵の「ノヴェル」の保持“. In: Waseda daigaku daigakuin bungaku kenkyū ka 早稲田大学大学院文学研究科 (54-03): 35-45.

Oraić Tolić, Dubravka (1995): Das Zitat in Literatur und Kunst: Versuch einer Theorie. (Nachbarschaften - Humanwissenschaftliche Studien, 4). Wien: Böhlau-Verlag.

Ōuchi, Hatsuo 大内初夫 (1979): „Fueki ryūkō ron no seiritsu 不易流行論の成立: chōto angya no fukamaru naka de 長途行脚の深まる中で: Bashō no kiseki 芭蕉の軌跡: shussei kara Kareno no kanata e 出生から枯野の彼方へ“. ‘Oi no kobumi’ no tabi kara ‘Oku no hosomichi’ e「笈の小文」の旅から「おくのほそ道」へ (Jōkyō 4 nen - Genroku 2 nen 1687-1689) (貞享 4 年 囚元禄 2 年 1687 \1689). In: Kokubungaku kaishaku to kyōzai no kenkyū 国文学解釈と教材の研究 (24 (13): 99-104.

Owen, Stephen (1992): Readings in Chinese Literary Thought. (Harvard-Yenching Institute Monograph Series, 30). Cambridge (Mass.): Harvard University Press.

Pohl, Karl-Heinz (2007): Ästhetik und Literaturtheorie in China: Von der Tradition bis zur Moderne. (Geschichte der chinesischen Literatur, 5). München: Saur. 
Pollack, David E. (1986): The fracture of meaning: Japan's synthesis of China from the eighth trough the eighteenth centuries. Princeton, N.J.: Princeton University Press.

Quenzer, Jörg (1996): „“Verweilen im Wahn der Welt”: Das sechste Kapitel der Sammlung Sarumino von Bashō. Einführung, Übersetzung und Kommentar“. In: Nachrichten der Gesellschaft für Natur- und Völkerkunde Ostasiens e.V. (159-160): 131-172.

Quenzer, Jörg (2008): „Fiktion und Liebe im Genji monogatari“. In: Nachrichten der Gesellschaft für Natur- und Völkerkunde Ostasiens e.V. (183-184): 61-73.

Rafetseder, Hermann (1988): Bücherverbrennungen: Die öffentliche Hinrichtung von Schriften im historischen Wandel. (Kulturstudien, 12). Wien: Böhlau-Verlag.

Regelsberger, Andreas (2004): „Theater an der hauchdünnen Grenze zwischen Wahrheit und Schein: Betrachtungen zur Ästhetik des Jōruri aus dem Naniwa miyage (1738)“. In: Sünden des Worts. Festschrift für Roland Schneider zum 65. Geburtstag (Hgg. Árokay, Judit und Vollmer, Klaus). (Gesellschaft für Natur- und Völkerkunde Ostasiens: Mitteilungen der Gesellschaft für Natur- und Völkerkunde Ostasiens e.V. Hamburg, 141): 79-108.

Reicher, Maria E. (Hg.) (2007): Fiktion, Wahrheit, Wirklichkeit: Philosophische Grundlagen der Literaturtheorie. (KunstPhilosophie, 8). Paderborn: Mentis-Verlag.

Rimer, J. Thomas (2002): „Hegel in Tōkyō: Ernest Fenollosa and His 1882 Lecture on the Truth of Art“. In: Japanese Hermeneutics: Current Debates on Aesthetics and Interpretation (Hg. Marra, Michael F.; Honolulu, Hawaii: University of Hawai'i Press): 97-108.

Rimer, J. Thomas and Yamazaki, Masakazu (1984): On the Art of the Nō Drama: The Major Treatises of Zeami. Princeton (N.J.): Princeton University Press.

Rodd, Laurel Rasplica und Henkenius, Mary Catherine (1996): Kokinshū: A collection of poems ancient and modern including a study of Chinese influences on the Kokinshū prefaces by John Timothy Wixted and an annotated translation of the Chinese preface by Leonard Grzanka. (C \& T Asian literature series). Boston, MA: Cheng \& Tsui Co.

Roetz, Heiner (1992): Die chinesische Ethik der Achsenzeit: Eine Rekonstruktion unter dem Aspekt des Durchbruchs zu postkonventionellem Denken. Frankfurt am Main: Suhrkamp.

Roetz, Heiner (1995): Konfuzius. (Beck'sche Reihe, 529: Denker). München: C.H. Beck’sche Verlagsbuchhandlung.

Ryan, Marleigh Greyer (1975): The Development of Realism in the Fiction of Tsubouchi Shōyō. (Publications on Asia of the Institute for Comparative and Foreign Area Studies, 26). Seattle: University of Washington Press, 1975.

Saeki, Junko 佐伯順子 (1994): ,'Bi’ e no akogare「美」への憧れ“. Rensai 連載: “Bunmei kaika” no fūkei「文明開化」の風景 - 6. In: Nihon no bigaku 日本の美学 (21 (1994): 178-190.

Saeki, Junko 佐伯順子 (2001): „Longing for “Beauty”“. In: A history of modern Japanese aesthetics (Hg. Marra, Michael F.; Honolulu: University of Hawai'i Press): 25-42.

Sanekata, Kiyoshi 実方清 (1974): „Bungei riron ni okeru kajitsu ron 1 文芸理論における花実 論-1: Shinshi ron to kyojitsu ron no kanren ni oite 心詞論と虚実論の関連において“. In: Nihon bungei kenkyū 日本文藝研究 (26 (3): 1-12.

Sanekata, Kiyoshi 実方清 (1975): „Bungei riron ni okeru kajitsu ron 2 文芸理論における花実 論-2: Shinshi ron to kyojitsu ron no kanren ni oite 心詞論と虚実論の関連において“. In: Nihon bungei kenkyū 日本文藝研究 (27 (2): 1-10.

Sanekata, Kiyoshi 実方清 (1975): „Bungei riron ni okeru kajitsu ron 3 文芸理論における花実 論-3: Shinshi ron to kyojitsu ron no kanren ni oite 心詞論と虚実論の関連において“. In: Nihon bungei kenkyū 日本文藝研究 (27 (4): 1-12. 
Sargent, G. W. (1959): The Japanese family storehouse: Or The millionaires' gospel modernised: Nippon eitai-gura or Daifuku shin chōja kyō (1688). (University of Cambridge Oriental Publications, no. 3). Cambridge: Cambridge University Press.

Satō, Katsuaki 佐藤勝明 (2006): Bashō to Kyōto haidan 芭蕉と京都俳壇: Shōfū taidō no Enpō - Tenna ki wo kangaeru 蕉風胎動の延宝・天和期を考える. Tōkyō: Yagi shoten 八木書店.

Schamoni, Wolfgang (1975): „Die Entwicklung der Romantheorie in der japanischen

Aufklärungsperiode“. In: Nachrichten der Gesellschaft für Natur- und Völkerkunde Ostasiens e.V. (118): 9-39.

Schamoni, Wolfgang (1992): Literature and Modernization in Japan: The Changing Geography of Literary Genres 1850-1890. (The Richard Storry Memorial Lecture, No. 4; 2nd May 1991). Oxford: St. Antony's College.

Schamoni, Wolfgang (2000): „The Rise of “Literature” in Early Meiji: Lucky and Unlucky Genres“. In: Canon and Identity - Japanese Modernization Reconsidered: Trans-Cultural Perspectives (Hg. Hijiya-Kirschnereit, Miscellanea, 14; Irmela; Berlin: Deutsches Institut für Japanstudien): 37-60.

Schaumann, Werner Gustav (1981): Kanagaki Robun, ein japanischer Unterhaltungsschriftsteller in der frühen Zeit der Modernisierung. Dissertation. Bonn Universität.

Schmidt-Glintzer, Helwig (1990): Geschichte der chinesischen Literatur: Die 3000jährige Entwicklung der poetischen, erzählenden und philosophisch-religiösen Literatur Chinas von den Anfängen bis zur Gegenwart. Bern: Scherz.

Searle, John R. (1974-1975): „Der logische Status fiktionaler Rede“. In: Fiktion, Wahrheit, Wirklichkeit: Philosophische Grundlagen der Literaturtheorie (Hg. Reicher, Maria E.; KunstPhilosophie, 8; Paderborn: Mentis-Verlag, 2007): 21-36.

Shaughnessy, Edward L. (1997): I Ching: The classic of changes. New York: Ballantine Books. Shigematsu, Yasuo 重松泰雄 (1979): „Botsu risō ronsō 没理想論争“. In: Tsubouchi Shōyō Futabatei Shimei 坪内覓遥・二葉亭四迷 (Hg. Nihon Bungaku Kenkyū Shiryō Kankōkai 日 本文学研究資料刊行会). (Nihon bungaku kenkyū kihon sōsho 日本文学研究基本叢書; Tōkyō: Yūseidō Shuppan 有精堂出版): 90-96.

Shimamura, Daishin 島村大心 (2009): „“Mōjin kangen kan” ni tokareru kaiin sanmai to shinri no naijitsu 『妄尽還源観』に説かれる海印三昧と真理の内実“. In: Mikkyō gaku 密教学 (45): 51-85.

Shimizu, Shigeru 清水茂 (1983-1985): „Buntai meiben 文体明弁“. In: Nihon koten bungaku daijiten 日本古典文学大辞典 5 ( Hg. Nihon Koten Bungaku Daijiten Henshū linkai 日本古典 文学大辞典編集委員会; Tōkyō: Iwanami Shoten 岩波書店): 378-379.

Ströker, Elisabeth (1983): „Was ist das Imaginäre in Isers Fiktionalitätstheorie?“. In: Funktionen des Fiktiven (Hgg. Henrich, Dieter und Iser, Wolfgang; Poetik und Hermeneutik, 10; München: Fink): 473-478.

Sugaya, Hiromi 菅谷広美 (1979): „“Shōsetsu shinzui” to sono zaigen『小説神䯣』とその財 源“. In: Tsubouchi Shōyō - Futabatei Shimei 坪内逍遥・葉亭四迷 (Hg. Nihon Bungaku Kenkyū Shiryō Kankōkai 日本文学研究資料刊行会; Nihon bungaku kenkyū kihon sōsho 日 本文学研究基本叢書; Tōkyō: Yūseidō Shuppan 有精堂出版): 13-31.

Suzuki, Sadami 鈴木貞美 und Tyler, Royall (2006): The Concept of “Literature” in Japan. (Nichibunken monograph series, 8). Kyōto 京都: International Research Center for Japanese Studies.

Takagi, Sōgo 高木蒼梧 (1955): „Bashō to Butchō zenshi 芭蕉と仏頂禅師“. In: Daihōrin 大法輪 (22 (5): 68-71. 
Takahashi, Masao 高橋昌郎 (1966): Nakamura Keiu 中村敬宇. (Jinbutsu sōsho 人物叢書, 135). Tōkyō: Yoshikawa Kōbun Kan 吉川弘文館.

Terayoko, Takeo 寺横武夫 (1978): „Futabatei Shimei ni okeru ‘Reiun sha’ no hassō 二葉亭四迷 における「冷雲社」の発想: Gi Shukushi sesshu no ichi sokumen 魏叔子摂取の一側面“. In: Nihon kindai bungaku 日本近代文学 (25 (1978-10): 85-101.

Thomas, Roger K. (2004): „A Voice of the Tenpō Era: The Poetics of Ōkuma Kotomichi“. In: Monumenta Nipponica (Vol. 59, No. 3 (Autumn, 2004): 321-358.

Togawa, Shinsuke 十川信介 (1967): „Bungaku to shizen 文学と自然: Sōjitsu ron wo megutte 想実論をめぐって“. In: Nihon kindai bungaku 日本近代文学 (7 (Nov. 1967): 1-13.

Togawa, Shinsuke 十川信介 (1967): „“Jissō” to “kyosō”『実相』と『虚相』“. In: Bungaku 文 学 (35.1 (1967.02): 53-64.

Tsuchiya, Momoko 土谷桃子 (2009): Edo to Meiji wo ikita gesakusha 江戸と明治を生きた戯作 者: Sansantei Arindo - Jōno Saigiku sanjin 山及亭有人・条野採菊散人. Tōkyō: Kindai Bungei Sha 近代文芸社.

Tsukagoshi, Yoshiyuki (1986): „“Inaka no kuawase” jo shōkō『田舎の句合』序小考: ‘Toshi ga share’ no dedokoro wo megutte「杜子がしやれ」の出所をめぐっで. In: Nihon bungaku ronkyū 日本文學論究 (45): 92-100.

Tucker, John Allen (2006): Ogyū Sorai’s Philosophical Masterworks: The "Bendō" and "Benmei". (Asian Interactions and Comparisons). Honolulu: University of Hawai'i Press.

Twine, Nanette (1981): The Essence of the Novel: Tsubouchi Shōyō. (Occasional Papers, 11). Queensland: University of Queensland Press.

Ueda, Atsuko (2005): „The Production of Literature and the Effaced Realm of the Political“. In: Journal of Japanese Studies 31.1: 61-88.

Ueda, Atsuko (2007): Concealment of politics, politics of concealment: The production of "literature" in Meiji Japan. Stanford (Calif.): Stanford University Press.

Ueda, Makoto 上田真 (1967): Literary and Art Theories in Japan. (Michigan classics in Japanese studies, no. 6). Ann Arbor: Center for Japanese Studies University of Michigan, 1991.

Usami, Bunri 宇佐美文理, Ogasa, Tomoaki 小笠智章, Jiao, Kun 焦妿, Sun, Luyi 孫路易, Naka, Sumio 中純夫 und Fukutani, Akira 福谷彬 (2009): „“Shushi gorui” kan 14-18 yakuchū 『朱子語類』巻一四〜一八訳注: 1 -“. In: Kyōto furitsu daigaku gakujutsu hōkoku Jinbun 京都府立大学学術報告- 人文 (61): 53-142.

Usui, Yoshimi 臼井吉見 (1975): Kindai bungaku ronsō 近代文学論争 (2 Bde.). (Chikuma sōsho 筑摩叢書, 217, 218). Tōkyō: Chikuma Shobō 筑摩書房.

Voloshinov, V. N., Matejka, Ladislav and Titunik, I. R. (1986): Marxism and the philosophy of language. Cambridge, Mass.: Harvard University Press.

Wagner, Andreas (1996): „Gattung und „Sitz im Leben«: Zur Bedeutung der formgeschichtlichen Arbeit Hermann Gunkels (1862-1932) für das Verstehen der sprachlichen Größe »Text«“. In: Texte - Konstitution, Verarbeitung, Typik (Hgg. Michaelis, Susanne und Tophinke, Doris; Edition Linguistik, 13; München: LINCOM Europa): 117-129.

Watson, Burton (1968): The complete works of Chuang-tzu. (Records of Civilization - Sources and Studies, 80). New York: Columbia University Press.

Watson, Michael (2020): „Premodern Japanese Narratives and the Problem of Referentiality and Factuality“. In: Narrative Factuality: A Handbook (Hgg. Fludernyk, Monika und Ryan, Marie-Laure; Revisionen der Grundbegriffe der Literaturtheorie, 6; Berlin: Walter de Gruyter): 663-675. 
Wehlert, Heide (1971): „Essay über Form und Gefühlsgehalt - ein Kapitel aus dem Haikai jūron des Kagami Shikō (1665-1731)“. In: Asien. Tradition und Fortschritt: Festschrift für Horst Hammitzsch zu seinem 60. Geburtstag (Hgg. Brüll, Lydia und Kemper, Ulrich; Wiesbaden: Harrassowitz Verlag): 645-652.

Wellek, René and Warren, Austin (1985): Theorie der Literatur. (Athenäum taschenbücher: Literaturwissenschaft, AT 2005). Königstein: Athenäum.

Werner, Thomas (2007): Den Irrtum liquidieren: Bücherverbrennungen im Mittelalter. (Veröffentlichungen des Max-Planck-Instituts für Geschichte, 225). Göttingen: Vandenhoeck \& Ruprecht.

Wilhelm, Richard (1992): Dschuang Dsi [Zhuangzi]: Das wahre Buch vom südlichen Blütenland. Aus dem Chinesischen übertragen und erläutert von Richard Wilhelm. 7. Aufl. Köln: Eugen Diederichs.

Wilhelm, Richard und Ess, Hans van (2008): Die Lehren des Konfuzius: Die vier konfuzianischen Bücher. Frankfurt/Main: Zweitausendeins.

White, Hayden V. and Koselleck, Reinhart (1991): Auch Klio Dichtet Oder Die Fiktion Des Faktischen: Studien zur Tropologie Des Historischen Diskurses. Stuttgart: Klett-Cotta. Wixted, John Timothy (2009): „Mori Ōgai: Translation Transforming the Word / World“. In: Japonica Humboldtiana (13): 61-109.

Wilson, William Scott (2006): The flowering spirit: Classic teachings on the art of Nō. Tōkyō: Kodansha International.

Woldering, Guido (1993): „Die Sieben Prinzipien des historisierenden Romanes des Takizawa Bakin: Übersetzung und Kommentar“. In: Bochumer Jahrbuch zur Ostasienforschung (17): 77-102.

Woldering, Guido (1998): Kommunikative und expressive Graphie bei Takizawa Bakin (17671848): Untersuchung zweier Abschnitte aus dem japanischen Abenteuerroman Nansō Satomi Hakkenden anhand eines zeitgenössischen Standard-Nachschlagewerkes. (Europäische Hochschulschriften, Reihe 27, Asiatische und afrikanische Studien, 65). Frankfurt am Main: Lang.

Woldering, Guido (2015): „Bijutsu no hongi (1885) und Shōsetsu sōron (1886) von Futabatei Shimei: Die Emanzipation der japanischen Erzählprosa zu einer Kunstform“. In: Bunron 文 論, 2(2): 15-47. Online verfübar unter: http://crossasia-journals.ub.uni-heidelberg.de/ index.php/bunron/article/view/658

Woldering, Guido (2015): „Fiktion und Wirklichkeit in der japanischen Literaturtheorie der Jahre 1850 bis 1890: Mori Ōgais "Bungaku to shizen“ wo yomu” (1889)“. In: Nachrichten der Gesellschaft für Natur- und Völkerkunde Ostasiens e.V. (189-190 (2013/14): 57-126.

Yamamoto, Shōichi 山本昌一 (1979): „Tsubouchi Shōyō 坪内逍遥: Botsu risō ronsō wo megutte 没理想論争をめぐって“. In: Tsubouchi Shōyō - Futabatei Shimei 坪内逍遥・二葉 亭四迷 (Hg. Nihon Bungaku Kenkyū Shiryō Kankōkai 日本文学研究資料刊行会; Nihon bungaku kenkyū kihon sōsho 日本文学研究基本叢書, Tōkyō: Yūseidō Shuppan 有精堂出 版): 106-113.

Yamashita, Samuel Hideo (1997): „Nature and Artifice in The Writings of Ogyū Sorai (16661728)“. In: Confucianism and Tokugawa culture (Hg. Nosco, Peter; Honolulu, Hawaii: University of Hawai'i Press): 138-165.

Yamauchi, Shōshi 山内祥史 (1979): „Shōyō ni okeru botsu risō ronsō no keisei 逍遥における 没理想論争の形成“. In: Tsubouchi Shōyō - Futabatei Shimei 坪内逍遥・二葉亭四迷 (Hg. Nihon Bungaku Kenkyū Shiryō Kankōkai 日本文学研究資料刊行会; Nihon bungaku kenkyū kihon sōsho 日本文学研究基本叢書, Tōkyō: Yūseidō Shuppan 有精堂出版): 74-89. 
Yanabu, Akira 柳父章 (1982): Hon’yakugo seiritsu jijō 翻訳語成立事情. (Iwanami shinsho 岩波 新書, 189). Tōkyō: Iwanami Shoten 岩波書店.

Yanabu, Akira 柳父章 (1986): Goddo to jōtei ゴッドと上帝: Rekishi no naka no hon'yakusha 歴 史の中の翻訳者. (Iwanami gendai bunko 岩波現代文庫: Gakujutsu 学術). Tōkyō: Chikuma Shobō 筑摩書房, 2001.

Yanagida, Izumi 柳田泉 (1965): Meiji shoki no bungaku shisō 明治初期の文学思想 (2 Bde.). Tōkyō: Shunjūsha 春秋社.

Yanagida, Izumi 柳田泉 (1967): „Gi Shukushi to Futabatei Shimei 魏叔子と二葉亭四迷“. In: Futabatei Shimei 二葉亭四迷 (Hg. Shimizu, Shigeru 清水茂; Kindai bungaku kanshō kōza 近代文学鑑賞講座, 1; Tōkyō: Kadokawa Shoten 角川書店): 362-371.

Yokota, Fuyuhiko 横田冬彦 (2015): „Dokusho to dokusha 読書と読者“. In: Dokusho to dokusha 読書と読者 (Hg. Yokota, Fuyuhiko 横田冬彦; Shirīzu ‘Hon no bunka shi’ シリー ズ「本の文化史」, 1; Tōkyō: Heibonsha 平凡社): 11-34.

Yoshida, Seiichi 吉田精一 (1975): Kindai bungei hyōron shi 近代文芸評論史: Meiji hen 明治篇. Tōkyō: Shibundō 至文堂.

Yoshida, Seiichi 吉田精一 (1980): Kindai bungei hyōron shi 近代文芸評論史: Taishō hen 大正 篇. Tōkyō: Shibundō 至文堂.

Yoshida, Seiichi 吉田精一 (1980): Meiji no bungei hyōron 明治の文芸評論. (Yoshida Seiichi chosaku shū 吉田精一著作集, 3). Tōkyō: Ōfūsha 桜楓社.

Yuasa, Nobuyuki (1966): The narrow road to the Deep North and other travel sketches: Translated from the Japanese. (Penguin classics). Harmondsworth: Penguin, 1974.

Zeuch, Ulrike (2010): „Mimesis oder die Tauglichkeit literaturtheoretischer Begriffe zur Beschreibung ideengeschichtlicher Prozesse“. In: Literaturwissenschaft als Begriffsgeschichte (Hg. Strosetzki, Christoph; Archiv für Begriffsgeschichte, 8; Hamburg: Felix Meiner): 111-123.

Zhiyi 智顗 (ca. 594): Mohe zhiguan 摩訶止観. „The Great Calming and Contemplation“. In: Sources of Chinese tradition (Hgg. Bary, William Theodore de und Bloom, Irene; New York: Columbia University Press): 460-461.

Zhiyi 智顗, Donner, Neal Arvid and Stevenson, Daniel B. (1993): The great calming and contemplation: A study and annotated translation of the first chapter of Chih-i's Mo-ho chih-kuan. (Classics in East Asian Buddhism). Honolulu: University of Hawai'i Press.

Zipfel, Frank (1999): Fiktion, Fiktivität, Fiktionalität: Analysen zur Fiktion in der Literatur und zum Fiktionsbegriff in der Literaturwissenschaft. (Allgemeine Literaturwissenschaft Wuppertaler Schriften, 2). Berlin: Erich Schmidt Verlag, 2001. 